\title{
PARADOX OF EXCESS LIQUIDITY IN EUROPEAN EMERGING AND TRANSITION ECONOMIES*
}

\author{
Albulenë Kastratia iD
}

\begin{abstract}
European emerging and transition economies are in immense need of investments and renewal of capital, yet they produce a considerable amount of unutilized resources. In particular, banks hold excess liquidity in the face of seemingly profitable lending opportunities. Is it a demand-side or supply-side problem or is this region entirely different and have we been working under the wrong paradigm? This study creates a new estimate of excess liquidity by taking into account banks' overall liquidity position. Breaking down precautionary from involuntary excess liquidity, a significant presence of the latter is evident. A part of the story deals with insensitivity of deposits to interest rates. Based on our standard understanding of how banks work, this is puzzling and this study creates a new way to look at this. Using new measures is the way to launch the investigation of causes and policy implications for involuntary excess liquidity.
\end{abstract}

Keywords: Excess liquidity, emerging economies, banks, European countries JEL Classification: O16, G21, E52, E44, D60, D53

\section{Introduction}

Emerging and transition economies (EETEs) are in immense need for investments and renewal of capital, while they produce a considerable amount of unutilized resources. Being the main source of finance in transition economies, banks are often accused of restricting loans and consequently causing depressed economies, while having hands on vast amounts of money not being used - such as banking excess liquidity (EL). Conversely, banks point to insufficient demand for loans, market and institutional inefficiencies, claiming to be the actual victims. The EL is part of the financial economy but not part

* The author would like to thank the Fulbright Board, the U.S. Embassy in Prishtina, the Duke University, and Connel Fullenkamp for enabling this research project, Geoffrey Pugh and Ralph Chami for special contribution to the paper and two anonymous reviewers for comments and suggestions.

a Duke Unversity, USA and AAB College, Kosovo

Email: albulenekastrati@gmail.com 
of the productive economy and EETEs would certainly be better off if they could get banks to lend it out. Continuous accumulation of excess reserves is not a business strategy that profit-maximizing banks adopt. However, the economy structure and institutional quality could be preventing banks from lending.

Banks in EETEs have persistently accumulated liquid assets above their statutory requirement in central bank accounts and above the mandatory liquidity ratio. During 2000-2018, several EETEs accumulated on average a ratio of EL to total assets of 19 percent; Eastern European (EE) and South-Eastern European (SEE) regions have accumulated 25 percent (for example, Romania 40 percent, more developed central European (CE) economies around 13 percent (for example, Slovakia around 23 percent) and the Baltics around 13 percent.

In a transition economy where potential output is low (Kastrati, 2017) and enterprises may crave for working capital and longer-term investment, underutilization of financial resources is likely to be a crucial economic problem (Aikaeli, 2011). Although banks in EETEs are profitable, liquid, well capitalized and relatively stable, the provision of credit to support business investments remains weak and well below levels observed in developed Europe. The private sector lending in EETEs is considerably lower than in the Eurozone, suggesting deficient lending. On average, during 2000-2018 bank lending to the private sector was around 41 percent of $\mathrm{GDP}^{1}$ (central banks and World Bank, 2019), compared to around 92 percent in the Eurozone (ECB, 2019a; World Bank, 2019). Subdued lending is worrying, given that banks in many EETEs are the main funding source, with non-existent or underdeveloped capital markets.

The EL is typically non-remunerated even in more developed transition countries such as the Czech Republic, Poland and Hungary, and when it is remunerated, the earned interest is negligible. When remunerated (in some SEE countries), the rate is typically lower than the market rates, thus not providing an attractive rate of return. ${ }^{2}$ A portion of other liquid assets is turned around in treasury bills or placements abroad that often comprise more than one third of total assets, which yield lower rates of returns than deposits at the central bank, thus not providing much incentive for banks to hold EL. ${ }^{3}$ A part of the EETE commercial banks' deposits are placed in commercial banks of the Eurozone,

1 Credit/GDP reached 80 percent in Baltics and Slovenia for a short period prior to the GFC, but soon got back to 40 percent.

2 To encourage interbank trading, the remuneration rate on deposits in the central bank should be lower than the cost of borrowing from the central bank (IMF, 2004).

3 The difference between the average lending rate of 11.25 percent and the average EURIBOR rates is approximately $9.1 \mathrm{pp}$ (EMMI, 2019). This gap implies that investing in placements abroad provides less incentives compared to investments in loans. 
which are directly linked with the European Central Bank (ECB) deposit rates. In 2014, the ECB's rates turned negative, reducing earnings or creating losses.

Loans are the most profitable assets to hold, more so when compared to the lending rates in developed Europe. The nominal loan rates in most of the European transition economies during 2000-2019 were above 10 percent (World Bank, 2019) compared to around 4.2 percent in the Eurozone (ECB, 2019a). The net interest margin in EETEs has been around 5 percent, compared to the 1.8 net interest margin in the Eurozone (World Bank, 2019; ECB, 2019a), suggesting that EETEs are a frontier of profitable loans. One reason for setting high lending rates may be to compensate for the relatively higher non-performing loan ratio (NPL), compared to the NPL ratio in Eurozone countries. In reality, this may not be the case. Additional lending may only be possible at higher levels of risk, which may be outside the bank's own risk tolerance threshold. However, a visual depiction of lending interest rates versus NPLs by country indicates a fairly weak correlation. After adjusting return rates with the default rates, banks in EETEs seem to be earning a higher loans margin; thus, lending rates are not necessarily set high enough to offset the repayment risk.

The mystery heightens on the liability side, since banks accept deposits that they do not seem interested in using and are costly to hold (on average 2000-2019, deposit rates were 4.2 percent). The relatively high level of deposits suggests that they are not constraining the banking lending ( 60 percent of total assets in EETEs compared to 50 percent in the Eurozone; respective central banks and ECB, 2019a). The ratio of private sector loans to total deposits is around 85 percent (compared to 60 percent in the Eurozone), suggesting further capacity to extend lending. Reliance on domestic deposits to finance lending has lessened banks' exposure to external risks and has contributed to relatively stable liquidity conditions. The EL thus held seemingly reduces bank's earnings because deposits are costly, thereby reducing capital and increasing banks' vulnerability. Relatively high interest rate spreads make EL not only costly but may also infer opportunity costs of holding it.

Are banks having trouble lending? High profitability suggests that they are not. Thus, lending seems not right, precisely where it is needed most. ${ }^{4}$ Is it a demand-side or supply-side problem, or is it just not the right paradigm in a transition context? If it was used to increase domestic lending, would it raise investment and aggregate demand and hence augment welfare?

4 Accepting deposits while the bank has accumulated EL may also be a long-term strategic plan to build market share. However, only after the disaggregation between $R_{P}$ and $R_{I}$ in Section 4 will we be able to judge if this is the case. 
There has been very little thinking about the EL paradox in this region and not that much globally as it is not well understood. This is an intellectually important topic but to the best of our knowledge, no one has yet got a policy response to it. EETEs would be a good place to learn about this phenomenon that could hold lessons for the rest of the world.

The study redefines the EL concept by taking into account the overall banking liquidity position, i.e., EL in a central bank's account and EL in commercial banks' accounts. This analysis adds to the limited theoretical and empirical analysis of the role of EL as an unutilized financial resource in a developing context from regulators', banks' and borrowers' perspective. New results using original estimates of EL are presented. This study finds interesting insights from the deposit market, which is typically ignored in the previous literature. The methodology estimating explicit costs and opportunity costs of forgone returns from involuntary EL is also novel.

This paper finds that involuntary EL is present and significant throughout the period examined, implying costs for banks and deadweight loss for the economy. Findings that EL and market power prevent the pass-through to market rates could be broadly applicable; that the policy rate serves only as an opportunity cost and not as a funding cost may be applicable in other parts of the developing world, whereas learning that banks in EETEs also profit from the liability side was surprising.

The rest of the paper is organized as follows. Section 2 proposes a new EL definition and discusses the literature review. Sections 3 and 4 explain the new EL calculation methodology, estimated results and disaggregation between precautionary and involuntary EL. Section 5 provides conclusions and policy implications.

\section{Theoretical Background}

\subsection{Definition of excess liquidity}

The concept of excess liquidity is frequently treated imprecisely, if at all, in the literature on developed countries, though it has also been neglected in empirical studies on developing and transition countries. Conceptually, liquid assets represent the sum of the financial assets that can be quickly mobilized for lending or other purpose transactions. The question posed is how much of those liquid assets is in excess of what is needed for banks to conduct daily transactions and comply with the regulations of the domestic money markets, as this part is not considered "excess". Different authors, based on theory and the practices of central banks, define EL differently (Figure 1). 


\section{Figure 1: Conceptual definition of excess liquidity}

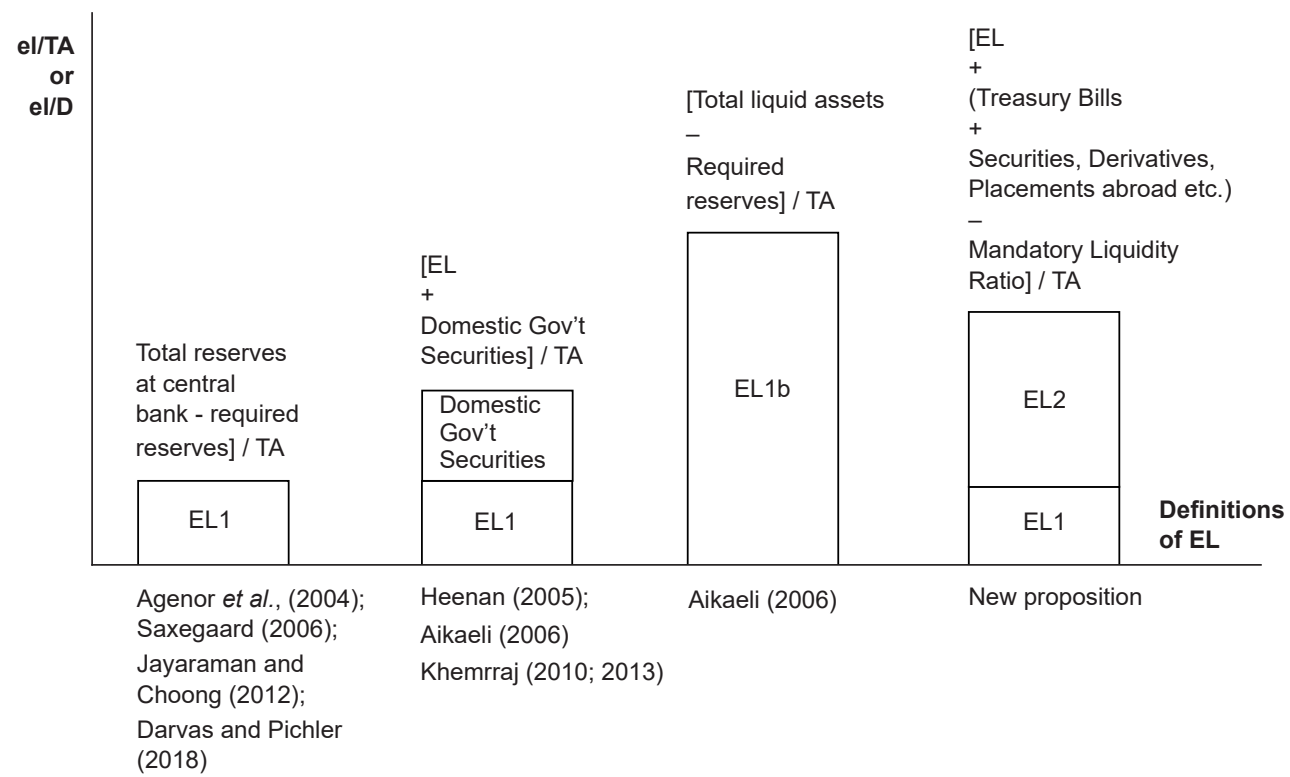

Source: Author

At the global level, Ruffer and Starcca (2006) define EL as the inverse of the "velocity of the money", pointing to the money supply non-circulating in the economy. At the bank level, Agénor et al. (2004), Saxegaard (2006) and Choong (2012) define EL as the quantity of cash and deposits of commercial banks held $(d)$ with the central bank in excess of the required reserves $(R R)$ on deposits. In a Eurozone context, ECB (2017) and Darvas and Pichler (2018) define it as "all sorts of deposits" held by the Euro system minus $R R$. The first definition is partially correct because it represents what is "excess" but only from the central bank's point of view (Equation 1).

$$
e l 1=d-R R .
$$

Nevertheless, this definition includes a small portion of liquid assets and disregards commercial banks' overall liquidity position. Aikaeli (2011) subtracts $R R$ form total liquid assets $(L A)$ to generate EL. This definition is closer to our proposed definition as it considers overall liquidity position, but may still be imprecise because it only subtracts $R R$ from deposits $(d)$ at the central bank and disregards other regulatory restrictions applicable for the rest of the banking liquid assets.

We propose a new definition which includes the overall liquidity position - at central banks and in commercial banks' accounts: cash, treasury bills, placements in domestic 
and foreign banks, government bonds, other securities, repurchase agreements, and current accounts in other financial institutions (Equation 2). The EL at central banks el1 is the same as in Equation 1. To reveal EL from the rest of the liquid assets (el2), we need to subtract the mandatory liquidity ratio $(M L)$ from banks' total liquidity ratio $(L A)$. Even if an explicit mandatory liquidity ratio is not set by the regulator, based on liquidity risk management regulations and practitioners' knowledge, several liquidity restrictions apply, be it for the structure of liquid assets, maturity gaps, internal requirements set by the banks' management, haircuts, ratings, deposit concentration restrictions, stress-test scenarios, internal valuations such as Internal Liquidity Adequacy Assessment Process (ILAAP), and others. These restrictions prohibit the rest of the liquid assets to be fully considered "excess"; thus, $M L$ should be subtracted.

$$
\begin{aligned}
& \text { New proposition }=(d-R R)+(L A-M L)=e l 1+e l 2=e l, \\
& \text { el/TA }=\text { EL Ratio. }
\end{aligned}
$$

The advantage of the new proposition, motivated by the discussion in Section 1, is more appropriate in the EETE context since it considers a wider range of unutilized assets that are part of the financial economy but not of the productive economy. The disadvantage of this approach is that $M L$ is not always explicitly given and may need calibration (see 3.1 for details).

Yet, not all EL thus measured is considered excess, as it may simply reflect planned excess capacity voluntarily held for precautionary purposes (henceforth, $R_{P}$ ). As such, it may not be deemed as "excess" from banks' nor the economy's perspective. If, however, part of excess reserves are held as "non-remunerated reserves that do not provide a convenience return which off-sets the opportunity costs of holding them" (Saxegaard, 2006, p. 13), then it befits the definition of involuntary excess liquidity (henceforth, $R_{I}$ ). In addition to the implicit opportunity costs from forgone returns in loans, we add to this definition actual costs inferred from unwanted deposits, as further discussed in 2.2.

$$
E L=R_{P}+R_{I}
$$

\subsection{Sources of excess liquidity}

EL emerged as an important issue in developed countries after the onset of the global financial crisis (GFC); it had been present in the banking systems of EETEs persistently years before the GFC, implying that its presence goes beyond cyclical phases and economic fundamentals. Existing studies raise the fundamental question - is it a demand-side or supply-side issue? - yet do not approach EL from mainstream theories: Keynesianism and Neo-Classical analysis, as broader points of departure for analysis than particular theories. 
According to the Keynesian view, the banking market can fall prey to inter-temporal coordination problems, such as the inability of the interest rate to clear savings and investment plans, manifested in a build-up of EL. If so, the liquidity trap may be one possible outcome. Assuming that treasury bills and reserves are perfect substitutes, but the lending rate is too low to cover the intermediation costs, the expectations are that interest rates must rise and bill/bond prices fall; hence, fear of capital losses dissuades purchasing of securities; hence, banks would be better off holding reserves as they would have a higher yield rather than lending them. A monetary expansion by central banks leads to an increase in excess reserves, even beyond banks' prudential requirements, since interest rates cannot be lowered, because open-market operations are ineffective. The public savings and loan investments may be in equilibrium at any level of EL accumulated; nonetheless, this would represent equilibrium in a depressed economy with unutilized resources. However, the liquidity trap argument does not hold in terms of EETEs where markets operate with high interest margins (Table 1).

The Neo-Classical position on liquidity would be that, just as unemployment is evidence of a malfunction of labour markets, EL is an evidence of malfunction of the money and capital markets. Thus, central bank's interference to reduce EL in banks below what may be an equilibrium level would be useless. Any central bank intervention via monetary policy may have short-term effects but without sustainable long-term impact, as depositors and banks optimize their positions on the market (De Vroey and Malgrange, 2011).

These two competing mainstream theories typically assume highly efficient financial systems; thus, they may miss peculiarities of transition markets. There are significant a priori reasons to believe that EETEs are different given the common past experience. All EETEs have entered a transition process in a post-communist era, carrying through their mistrust in institutions from previous regimes, undergone structural reforms (building institutions, creating financial systems from scratch, establishing a market-based economy, privatization process), chronic macroeconomic imbalances (low levels of credit to GDP and low capital stock), still face institutional and market deficiencies concerning court efficiency and their banking systems are mainly foreign-owned. Most importantly, EETEs (including those in the Eurozone) have persistent EL in common, a trend confirmed for two decades now.

To safeguard themselves from unforeseen cash outflows, banks already hold a part of their deposits, as the $R R$ from the regulator that should serve as a precautionary measure against liquidity or other related risks (Mishkin, 2018). That said, the regulator's choice of $R R$ may not coincide with the bank's desired $R_{P}$. If $R R$ serves as a prudential tool to safeguard banks from unforeseen liquidity contingencies, why should banks hold more liquidity? Do banks have more information and better risk assessment than 
the regulator does? Banks may hold additional liquid assets when central banks frequently change the $R R$, in order to anticipate increases in the $R R$. During 2000-2019, in most of the EETEs the $R R$ followed a decreasing trend, some EETEs operated without a $R R$, whereas in Albania, the Czech Republic and Kosovo it was constant for almost three decades. Therefore, the risk argument associated with frequent $R R$ changes is not valid for our sample countries; the contrary is true.

\section{Table 1: Comparison of causes of excess liquidity between developed and emerging/ transition economies}

\begin{tabular}{|c|c|c|c|}
\hline \multicolumn{2}{|r|}{ Developed economies } & \multicolumn{2}{|c|}{ Emerging and transition economies } \\
\hline Author & Reasons & Author & Reasons \\
\hline $\begin{array}{l}\text { Darvas } \\
\text { and Pichler } \\
(2018)\end{array}$ & $\begin{array}{l}\text { Significant and unforeseen } \\
\text { accumulation of EL after September } \\
2008 \text {, due to a breakdown of normal } \\
\text { interbank market operations and } \\
\text { heightened risk and uncertainties. } \\
\text { Incentivised by ECB/FED/central banks' } \\
\text { quantitative easing. }\end{array}$ & $\begin{array}{l}\text { Bird and Rajan } \\
\text { (2003); Jeanne and } \\
\text { Ranciere (2011); } \\
\text { Park and Estrada } \\
\text { (2010); Khemrraj } \\
\text { (2013) }\end{array}$ & $\begin{array}{l}\text { Persistent accumulation of EL before } \\
\text { and after global financial crisis - } \\
\text { there must be structural reasons. } \\
\text { Possible explanations exceed } \\
\text { those explained by economic } \\
\text { fundamentals. }\end{array}$ \\
\hline $\begin{array}{l}\text { Darvas } \\
\text { and Pichler } \\
(2018)\end{array}$ & $\begin{array}{l}\text { Quantitative easing and relatively un- } \\
\text { constrained access to ECB funding. Led } \\
\text { to overborrowing from commercial banks, } \\
\text { which translated into excess liquidity. }\end{array}$ & $\begin{array}{l}\text { Mishra et al. (2010); } \\
\text { Khemraj (2013) }\end{array}$ & $\begin{array}{l}\text { Because of a priori presence } \\
\text { of excess liquidity, banks do not } \\
\text { need to borrow as much from } \\
\text { central bank. }\end{array}$ \\
\hline $\begin{array}{l}\text { Illes et al. } \\
(2015)\end{array}$ & $\begin{array}{l}\text { Policy rate represents a marginal } \\
\text { financing cost. }\end{array}$ & $\begin{array}{l}\text { Jovanovic et al. } \\
\text { (2015) }\end{array}$ & $\begin{array}{l}\text { Policy rate is an opportunity cost, } \\
\text { not a financing cost. }\end{array}$ \\
\hline $\begin{array}{l}\text { Khemraj } \\
(2013)\end{array}$ & $\begin{array}{l}\text { Banks not lending because of low } \\
\text { interest rate (zero-bound interest rate) } \\
\text { and weak banks. }\end{array}$ & Khemraj (2013) & $\begin{array}{l}\text { Banks are not lending even at mark-up } \\
\text { rates. The liquidity trap could occur } \\
\text { at a non-zero bound interest rate. }\end{array}$ \\
\hline $\begin{array}{l}\text { Saxegaard } \\
(2006)\end{array}$ & $\begin{array}{l}\text { Lending rates too low to cover } \\
\text { intermediation costs - liquidity trap. }\end{array}$ & $\begin{array}{l}\text { Mishra et al. (2010); } \\
\text { Khemraj (2013) }\end{array}$ & $\begin{array}{l}\text { High lending interest rates as low } \\
\text { income level may not enable banks } \\
\text { to reap enough economies of scale. }\end{array}$ \\
\hline $\begin{array}{l}\text { Nguyen } \\
\text { et al. (2019) }\end{array}$ & $\begin{array}{l}\text { Low policy interest rate: benefit } \\
\text { of converting reserves into loans is low } \\
\text { due to low loan return rate and may fail } \\
\text { to cover transaction costs. }\end{array}$ & $\begin{array}{l}\text { Torre et al. (2007); } \\
\text { Khemraj (2009; } \\
\text { 2013) }\end{array}$ & $\begin{array}{l}\text { Mark-up lending rate (above } \\
\text { transaction cost rate) set by banks } \\
\text { due to small number of banks and } \\
\text { oligopolistic competition. }\end{array}$ \\
\hline $\begin{array}{l}\text { Darvas } \\
\text { and Pichler } \\
(2018)\end{array}$ & $\begin{array}{l}\text { EL accumulated due to liquidity trap } \\
\text { caused by expansionary monetary } \\
\text { policy and low interest rates under } \\
\text { unchanged loan demand. }\end{array}$ & $\begin{array}{l}\text { Hashi and Toçi } \\
\text { (2010) }\end{array}$ & $\begin{array}{l}\text { Credit rationing under persistently } \\
\text { relatively high lending rates, from } \\
\text { frictions deriving from asymmetry } \\
\text { of information. EL present even } \\
\text { under persistently high lending } \\
\text { rates. }\end{array}$ \\
\hline $\begin{array}{l}\text { Agénor and } \\
\text { Aynaoui } \\
\text { (2010); } \\
\text { Nguyen and } \\
\text { Boateng } \\
(2015) ;\end{array}$ & $\begin{array}{l}\text { Pass-through effect on market rates } \\
\text { is fairly rapid in more developed } \\
\text { countries. }\end{array}$ & $\begin{array}{l}\text { Petrevski and } \\
\text { Bogoev (2012); } \\
\text { Haughton and } \\
\text { Iglesias (2012) }\end{array}$ & $\begin{array}{l}\text { Interest rate pass-through less } \\
\text { responsive (or ineffective) to deposit } \\
\text { and lending rates due to higher } \\
\text { asymmetric information and } \\
\text { oligopolistic power. Central banks } \\
\text { rely more on indirect instruments. }\end{array}$ \\
\hline
\end{tabular}




\begin{tabular}{|c|c|c|c|}
\hline \multicolumn{2}{|r|}{ Developed economies } & \multicolumn{2}{|c|}{ Emerging and transition economies } \\
\hline Author & Reasons & Author & Reasons \\
\hline $\begin{array}{l}\text { Beaupain } \\
\text { and Durré } \\
(2016) ; E C B \\
(2017)\end{array}$ & $\begin{array}{l}\text { Interbank lending reduced significantly } \\
\text { due to lack of trust after GFC. Banks } \\
\text { were competing for funds from ECB } \\
\text { due to low rates, which led to EL } \\
\text { accumulation. }\end{array}$ & $\begin{array}{l}\text { Forssbæck and } \\
\text { Oxelheim (2007); } \\
\text { Mishra et al. (2010); } \\
\text { Hasanović and } \\
\text { Latić (2017) }\end{array}$ & $\begin{array}{l}\text { Underdeveloped/absent interbank } \\
\text { markets mainly due to restrictive } \\
\text { policies from parent banks, } \\
\text { conservative banking culture, } \\
\text { business model, etc. Thus, banks } \\
\text { rely more on deposits, even though } \\
\text { other banks have EL. }\end{array}$ \\
\hline $\begin{array}{l}\text { Montoro } \\
\text { and Moreno } \\
(2011)\end{array}$ & $\begin{array}{l}\text { Reserve requirement rate used } \\
\text { as monetary policy to sterilise EL. }\end{array}$ & $\begin{array}{l}\text { Jazbec and Kastrati } \\
\text { (2011) }\end{array}$ & $\begin{array}{l}\text { Reserve requirement rate may } \\
\text { not work as price stability is not } \\
\text { the main concern in TEs. Due to high } \\
\text { dependence on EU import, prices } \\
\text { closely mimic EU prices. }\end{array}$ \\
\hline $\begin{array}{l}\text { Morrison } \\
(1966)\end{array}$ & Inertia theory: fear of deposit outflow. & $\begin{array}{l}\text { KCA (2016); } \\
\text { Aliu et al. (2016); } \\
\text { Khemrraj (2013) }\end{array}$ & $\begin{array}{l}\text { Imperfect competition and } \\
\text { possibility of collusions. } \\
\text { Pronounced credit rationing } \\
\text { due to bank-dominated market } \\
\text { with oligopolistic/monopolistic } \\
\text { competition. }\end{array}$ \\
\hline $\begin{array}{l}\text { Darvas } \\
\text { and Pichler } \\
(2018) ; \\
\text { Beaupain } \\
\text { and Durré } \\
(2016)\end{array}$ & $\begin{array}{l}\text { Quantitative easing measures } \\
\text { from central banks; full-allotment } \\
\text { liquidity procedure against eligible } \\
\text { collateral. }\end{array}$ & $\begin{array}{l}\text { Hasanović } \\
\text { and Latić (2017) }\end{array}$ & $\begin{array}{l}\text { Lack of lending of last-resort } \\
\text { mechanism provided by central } \\
\text { bank. }\end{array}$ \\
\hline $\begin{array}{l}\text { Primus } \\
\text { (2017); } \\
\text { Ngyuen } \\
\text { et al. (2019). }\end{array}$ & $\begin{array}{l}\text { Banks cannot substitute deposits } \\
\text { perfectly with central bank funding } \\
\text { as this may require collateral, which } \\
\text { depletes liquid assets. }\end{array}$ & $\begin{array}{l}\text { Agénor and } \\
\text { Aynaoui (2010); } \\
\text { Nguyen et al. } \\
\text { (2015) }\end{array}$ & $\begin{array}{l}\text { The financial system is bank- } \\
\text { dominated and capital markets are } \\
\text { underdeveloped or illiquid. Deposits } \\
\text { are the main funding resource; no } \\
\text { alternative to borrowing from banks. }\end{array}$ \\
\hline $\begin{array}{l}\text { Darvas } \\
\text { and Pichler } \\
(2018)\end{array}$ & Weak banks, low growth prospects. & $\begin{array}{l}\text { Saxegaard (2006); } \\
\text { Khemrraj (2007). }\end{array}$ & $\begin{array}{l}\text { Inflow of remittances, FDls, } \\
\text { privatisation process. }\end{array}$ \\
\hline
\end{tabular}

Source: Author

Even if banks are unable to extend lending, one would expect them to decrease the level of unwanted deposits, to reduce deposit costs. The absence of other alternatives to depositing money (Agénor and Aynaoui, 2010; Nguyen et al., 2015) holds clients "captive audience" of their money and gives banks market power on the liability side of the balance sheet. ${ }^{5}$ The relatively high deposit supply reduces the deposit volatility risk and the need to borrow, thus reducing the need for $R_{P}$. Banks cannot discourage depositors, unless they put nominal deposit rates to zero, though following the global interest rates, this is actually the most recent practice.

5 Sometimes there are legal requirements of having banking accounts for citizens: salary transfers, visa applications, etc. 
a)

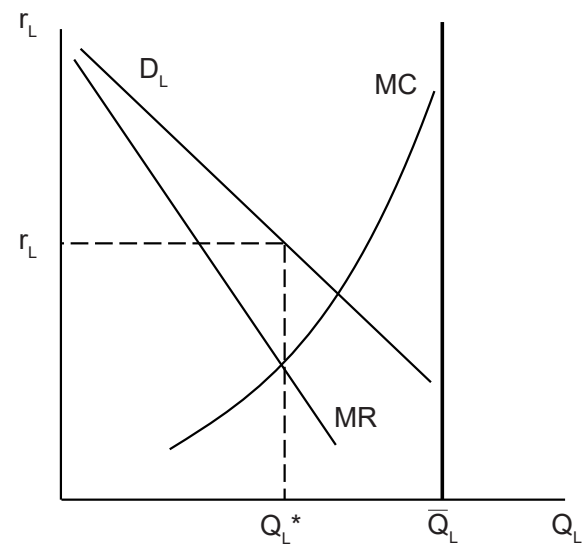

c)

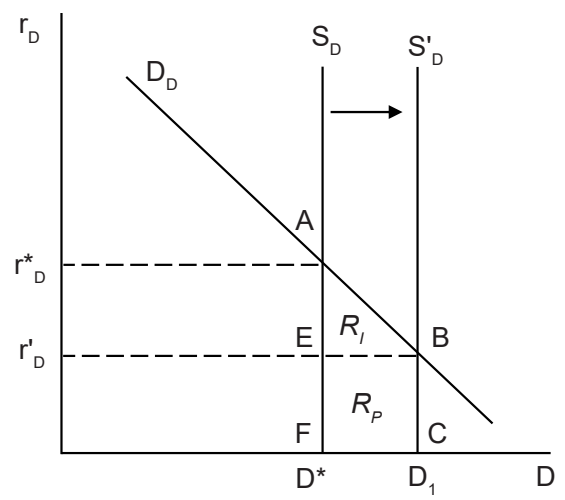

b)

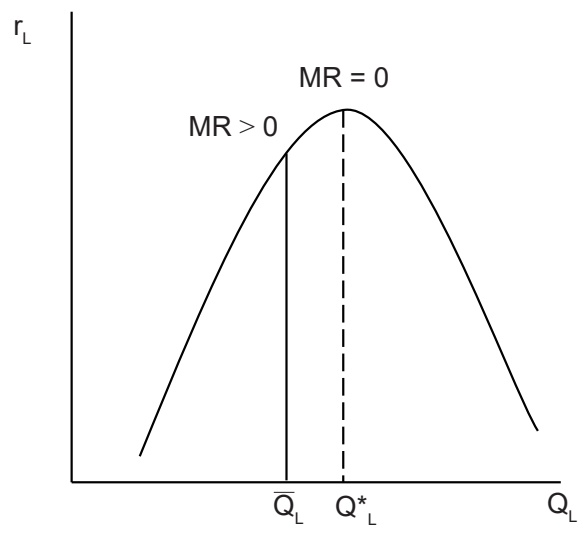

$\mathrm{ABCF}=$ Total Excess liquidity $\left(R_{p}+R_{h}\right)$

$\mathrm{ABE}=$ Deadweight loss $\left(R_{l}\right)$

Source: Author

A part of the unwanted deposits are invested in securities and deposits in foreign banks, often with a return as low as $0.1 \%$. Banks may be satisfied with the foreign rate they gain from foreign assets, since it may at least cover a part of their deposit costs; still that does not provide convenient returns that loans would.

Figure 2 presents two separate markets, a lending ( $2 \mathrm{a}$ and $2 \mathrm{~b}$ ) and a deposit market (2c). Figure 2a presents monopolistic banking competition, where banks choose to lend 
at $Q_{L}{ }^{*}$, which is less than the regulatory restrictions $\bar{Q}_{L}$. Figure $2 \mathrm{~b}$ presents discontinuity on the loan market at $M R>0$ as a non-optimizing behaviour. Figure $2 \mathrm{c}$ presents the situation of exogenous $S_{D}$, because of EL and irresponsiveness to $r_{D}$.

Table 2: Description of variables

\begin{tabular}{l|l|l|l}
\hline \multicolumn{2}{|c|}{ Lending market } & \multicolumn{2}{c}{ Deposit market } \\
\hline$r$ & Lending interest rate & $r_{D}$ & Deposit interest rate \\
\hline$Q_{L}$ & Quantity of loans & $r_{D}^{*}$ & Deposit rate chosen by banks \\
\hline$Q_{L}{ }^{*}$ & Banks choose desired quantity of loans & $r_{D}^{\prime}$ & Deposit rate because of RI \\
\hline$M R$ & Marginal revenues & $S_{D}$ & Exogenous supply of deposits \\
\hline- & $\begin{array}{l}\text { Quantity of loans constrained } \\
\text { by regulator }\end{array}$ & $D_{D}$ & Demand for deposits \\
\hline$Q_{L}$ & Demand for loans & $D^{*}$ & Desired level of deposits \\
\hline
\end{tabular}

Source: Author

A small number of operating banks, ${ }^{6}$ market concentration and possible non-cooperative collusions typically provide market power on the asset side of the balance sheet, too (Khemrraj, 2013; Huang and Liu, 2014; Aliu et al., 2016). ${ }^{7}$ Being closer to the market and having expertise and information exclusivity enables banks to cherry-pick customers and still be happy with $Q_{L}$ * (Figure $2 \mathrm{a}$ ). The market power enables them to use and misuse the information asymmetry as an excuse to set the $r_{L}$ beyond the $M R$, while the funding dependence on banks holds the loan demand inelastic to $r_{L}$. Because banks do not have funding problems, the central bank is not constraining them by the $R R$. The $R R$ is not binding because this constraint $Q_{L}$ is already above what banks choose as loan supply $Q_{L}$ and banks already choose monopolistic prices and quantity, where the required rate is on the other side of the equilibrium (Figure 2a). Adding together peculiarities from loan and deposit market leaves the market in a disequilibrium at the size of $R_{I}$ (Figure 2c). The disruptions discontinue lending before $\mathrm{MR}=0$ and not fully optimize their funds

6 The numbers of operating banks in EETEs vary from 10 and 14 in Kosovo and Montenegro to around 45 and 71 in the Czech Republic and Poland, respectively. The three largest banks in EETEs have consistently dominated around 60 percent of the total banking assets for the last 15 years, varying from around 55 percent in Bosnia and Herzegovina and Serbia to around 95 percent in Estonia (FRED Economic Data, 2019).

7 Some EETEs are prone to corruption and favouritism, which increases banks' costs, feeding into more oligopolistic competition. 
(Figure 2b). At this point, the actual lending is still profitable, but we do not know whether marginal lending is profitable. Thus, banks may maximize profit at the point where marginal profit is not equal to zero. This represents a non-optimizing behaviour.

So, why did not EETEs banks drop deposit rate to zero even in previous years? It may be because of supervisory pressures, regulatory requirements and social conventions that prevent them from rejecting deposits or possibly because of high adjusting costs. Banks have found a way to discourage depositors cheaply, by applying fees for depositing services so the $R_{I}$ does not hurt profits as much. Not facing competition from other financial intermediaries and capital markets (Mishra et al., 2010; Mishra et al., 2012) gives EETE banks market power on the liability side, so banks need not fight to attract deposits by manipulating the deposit rate. Additionally, FDI, donor funds and especially remittances reduce the effect of deposit rate manipulation to reach the desired level of deposits, i.e., deposits may be exogenous. Thus, it is the clients who necessarily pay for all the deposit fees and commissions. The average share of fees and commission income to total income in EETEs is around 20 percent, which represents a relatively high share in our view, compared to around 13 percent of total income of a small developed European country such as Luxemburg. Therefore, while profiting from the asset side, banks concurrently profit from the liability side - confirming the presence of $R_{r}$.

EL per se is not harmful for banks, but the opportunity costs of holding it are, if in the meantime other banks lend and reap profits. Nevertheless, in an imperfect competition other banks are not lending, either. With market power and asymmetric information, there seem to be no opportunity costs of $R_{r}$.

Following global trends, lending interest rates in EETEs have continuously decreased since 2011 onwards by around $4 \mathrm{pp}$, whereas lending spreads have only decreased by $1.5 \mathrm{pp}$ (World Bank, 2020). Higher spreads would normally encourage banks to lend more, not less, pointing to a supply-side problem. Even if lending rates decrease, the absorption capacity of these economies and the success rate of new projects may still be frail.

Are there (potential) borrowers in EETEs that are willing to apply for a loan even at the prevailing interest rates, but are they being denied? In EETEs, Hashi and Toçi (2010), Drakos and Giannakopoulos (2020) and Männasoo and Meriküll (2020) find significant evidence of denied credit and discouraged borrowers due to high collateral requirements. The underlying reasons for credit rationing may stem from the lack of a well-developed credit culture, inadequate infrastructure, collateral availability constraints, depth of credit information, and strength of legal rights (Doing Business, 2019). These frictions lower the ability to distinguish between high-risk and low-risk borrowers - translating into more adverse selection problems (Waller and Lewarne, 1994). Since neither pricing nor EL solve the adverse selection problem, banks become reluctant to reduce EL to attract 
new borrowers because it may result in increased defaults. Downgraded collateral due to certain property rights leads to over-collateralization of loans, even for good borrowers as is frequently the case in EETEs. ${ }^{8}$ By relying on too much collateral and less on screening criteria, banks become "lazy" (Manove et al., 2001) and may in turn contribute to more frictions. Doing Business indices indicate that these frictions are slowly moving away, meaning that conservative behaviour does not reflect the ultimate risks perceived in EETEs. However, such progress may only be "paper progress", since past experience (privatization, crisis, inflation, and weak governmental institutions) prior to 2000 still results in mistrust and risk aversion.

Banks are aware of $R_{I}$ as a residual that they may not be able to dispose of. Nevertheless, $R_{I}$ seems to affect banks' decisions on fees, placements abroad and government securities and possibly adds to the level of lending rate. In effect, area ABE (Figure 2c) is perceived as a deadweight loss, as a consequence of inefficient resource allocation. The welfare loss may be greater for consumers than banks, even though banks still incur explicit $\operatorname{costs}^{9}$ and implicit costs from forgone lending investment. Banks may not know (or be preoccupied) whether $R_{I}$ is constraining credit; nevertheless, it may deteriorate welfare on two fronts. Firstly, $R_{I}$ may create limitations on working capital, which prevents firms operating at full capacity. Secondly, it may constrain investment, which impedes the long-run rate of growth of actual and potential output. If so, $R_{I}$ as an unutilized financial resource should be a concern of regulators and policymakers.

Ultimately, why do central banks not sterilize EL from the markets? The ECB's quantitative easing measures and negative rates did not translate into the same amount of banking loans (Darvas and Pichler, 2018). They rather led to lower spreads between lending and deposit rates, thus hurting banks' profitability (Reuters, 2018). Contrary to the developed countries, where monetary instruments usually work in broad agreement with economic fundamentals (Nguyen and Boateng, 2015), in EETEs the link between policy rates and market rates is weak (Petrevski and Bogoev, 2012; Haughton and Iglesias, 2012). Firstly, the interbank market is an important transmission mechanism of monetary policy, where banks borrow at the policy rate plus a premium. In EETEs, only $0.4 \%$ of liabilities are subordinated loans. Usually, parent banks restrict their subsidiaries to expose to practically non-collateralized subordinated debt, in addition to regulatory limits. Secondly, without competition from other financial intermediaries, banks in EETEs easily raise liquidity from deposits, making the interbank markets redundant. Deposits are less costly and less risky than subordinated loans. Thirdly, banks

8 The average waiting days to enforce a contract in most EETEs is more than 500 days (Doing Business, 2019).

9 Deposit rates are on average higher than remuneration from T-bills. 
use EL to stabilize the loan supply in response to monetary policy changes (Benkovskis, 2008; Jimborean, 2009; Bogoev and Petrevski, 2012; Jovanovic et al., 2015; Nguyen et al., 2019).

Remittances might weaken monetary transmission from the demand side by providing a substitute for bank loans. Banks need not increase the deposit rate to attract remittances - they are altruistically motivated, so they will flow in regardless.

From a regulatory point of view, under a fixed amount of deposits, banks may be incentivized to apply a risk-sharing strategy between more liquid assets (less risky) and fewer loans (more risky assets), which may induce a socially inefficient allocation of resources (Primus, 2017). Banks can increase lending by decreasing the share of liquid assets or by increasing deposits, though this would require increasing capital levels. Capital is costly to raise and difficult to acquire given the lack of (functional) capital markets in EETEs. However, these trade-offs are purely incentivized by regulations and do not reflect the interaction between banks and the economy.

\section{Methodology and Data}

This section presents a novel approach to measuring EL by taking into account the overall liquidity position, tests the utility of a disaggregation method of $R_{P}$ and $R_{I}$ established by Saxegaard (2006) in a European context and presents the behaviour of EL across time and by country.

\subsection{Construction of excess liquidity as dependent variable}

The EL above the statutory requirements at central banks is a typical dependent variable in most studies examining this topic (Agénor et al., 2004; Saxegaard, 2006; Khemrraj, 2010). Such analysis portrays a partial story and defines EL only from the regulatory perspective. This approach can be improved by considering other parts of liquid assets in commercial banks' accounts, which on average range between 25 and 30 percent of total banking assets. ${ }^{10} \mathrm{~A}$ comprehensive measure of excess liquidity ratio (EL) needs both: excess liquidity at central banks (EL1) and excess liquidity in commercial banks' accounts (EL2). This approach may be particularly relevant in the EETE context, since banks hold relatively high ratios of liquid assets to total assets.

10 Banks' liquidity position includes: cash, treasury bills, placements in domestic and foreign banks (subject to short-term maturity), government bonds (subject to certain haircuts), other securities (subject to certain ratings and maturity), repurchase agreements, current accounts in other financial institutions (subject to certain haircuts) and other items. 
The $E L 1$ is easy to measure once data on $E L 1$ are available. However, measuring $E L 2$ is not always straightforward. Firstly, not all central banks in EETEs impose mandatory liquidity ratios $(M L)$. For example, Albania introduced the $M L$ in 2009, Hungary and North Macedonia in 2011 and Kosovo in 2012. The $M L$ was not a popular prudential measure during the 2000s, since regulators mainly concentrated on credit risk and capital requirements. The importance of $M L$ regained regulatory attention after the onset of the GFC. Most of the sample countries still have no $M L$, nonetheless report liquidity ratios for IMF needs or own supervisory purposes.

The ratio of liquid assets to short-term liabilities is a typical $M L$ in regulations, which if available in all EETEs would be used to subtract from liquidity position in banks' accounts. As a researcher, it is more sensible to use total assets as the common denominator for EL1 and EL2, as also reported by Baldo et al. (2017) and Darvas and Pichler (2018).

As discussed in 2.1 above, despite the lack of quantitative requirements $(M L)$, qualitative requirements have always been present (adequate maturity structure of assets and liabilities, liquidity reserve plans, cash inflow and outflow plans, ILAAP reports), preventing banks from using up all of their liquid assets. Based on the existing regulatory $M L s$ and a practitioner's knowledge, ${ }^{11}$ the following adjustments were made to calibrate $M L s$ for all the countries. For less developed banking systems with fewer safety nets and possible weaker rule of law (SEE and EE countries), the benchmark for the $M L$ ratio is set to 20 percent (compared to 25 percent ratio of liquid assets to short-term liabilities), whereas in the rest of the countries with better access to safety nets and possibly lower liquidity risk, the $M L$ ratio is set to 15 percent. The liquid asset ratios held above 20 percent and 15 percent, respectively, are considered to be $E L 2$ (e.g., liquid assets/total assets above 20 percent $=E L 2$ ). Lastly, $E L 1$ and $E L 2$ sum up to the total $E L$, used as the independent variable in this study:

$$
\begin{aligned}
& \text { EL Ratio }=(\text { Liquidity in Central Banks }=\text { Required Reserves })+ \\
& +((\text { broad }) \text { Liquid Assets to Total Assets }- \text { Mandatory Liquidity })= \\
& =\left(\frac{\text { EL at Central Banks }}{\text { Total Assets }}+\frac{\text { EL above Mandatory Ratio }}{\text { Total Assets }}\right) \times 100=\frac{\text { el } 1}{\text { Total Assets }} \times 100+ \\
& +\frac{\text { el } 2}{\text { Total Assets }}=E L 1+E L 2=E L \approx R_{P}+R_{I}
\end{aligned}
$$

The EL measured as in Equation 5 may be considered excess only from the regulatory point of view. Therefore, the disaggregation process of $R_{P}$ from $R_{I}$ takes place in 4.1.

11 The author has 10 years of working experience in a central bank. 
Ideally, this information would be acquired directly from banks. Nevertheless, it would not be practical to conduct such an exercise as an independent researcher in 17 EETEs.

\subsection{Data issues}

The country sample includes latecomers of the transition process, such as Albania, Bosnia and Herzegovina and Kosovo; Baltics as small open economies; and some of the more developed transition countries such as the Czech Republic and Poland, which have caught-up faster with developed Europe. ${ }^{12}$ The period examined is from 2000 to 2018. Since EL and liquidity ratios in many countries were only available annually, this study employs annual data.

Constructing the dependent variable and putting together an original dataset was the most challenging exercise because not all data were publicly or easily accessible, the disclosed data were inconsistently scattered in different PDF files, financial reports and separate files for each year from 2000 to 2018. The data were collected from annual reports, supervision reports, financial stability reports, balance sheets and income statements (Table 3). Additional data sources are from the World Bank, IMF World Economic Outlook (2019a), IMF Financial Soundness Indicators, IMF Country Reports and ECB monetary statistics and monthly bulletins (ECB, 2019b). Some financial reports needed translation into English, especially during the early 2000s. The collected data not available in euros were converted into euros by using the exchange rate of 31 December of each respective year.

A part of the EL data was obtained by contacting central bank officials in Albania, Bosnia and Herzegovina, Estonia, Hungary, Latvia, Lithuania, Moldova, Poland, Romania, Serbia and Slovakia. To construct EL2, the "broad" liquidity ratios were gathered from the IMF Financial Soundness Indicators database and, for the early 2000s, from the IMF country reports. Each country's regulatory framework was consulted as a guidance to calibrate the $M L s$.

12 The sample countries are: Albania, Bosnia and Herzegovina, Bulgaria, Croatia, the Czech Republic, Estonia, Hungary, Kosovo, Latvia, Lithuania, Moldova, North Macedonia, Poland, Romania, Serbia, Slovakia and Slovenia. Montenegro is removed from the sample because its time series starts from 2006. 
Table 3: Data sources

\begin{tabular}{|c|c|c|c|}
\hline Variable & Symbol & Description & Source \\
\hline $\begin{array}{l}\text { Excess } \\
\text { liquidity }\end{array}$ & $E L$ & $\begin{array}{l}\text { Ratio of excess liquidity (comprising above- } \\
\text { statutory reserves at central bank }+ \text { above- } \\
\text { mandatory liquidity ratio) over total assets. } \\
\text { In percent. }\end{array}$ & $\begin{array}{l}\text { IMF, respective central } \\
\text { banks }\end{array}$ \\
\hline $\begin{array}{l}\text { Volatility } \\
\text { of credit }\end{array}$ & VOLCRED & $\begin{array}{l}\text { Three-year moving average of standard } \\
\text { deviation of private sector credit to GDP. }\end{array}$ & $\begin{array}{l}\text { World Bank, respective } \\
\text { central banks and own } \\
\text { calculations }\end{array}$ \\
\hline $\begin{array}{l}\text { Squared } \\
\text { lending } \\
\text { interest rate }\end{array}$ & $I S Q R D$ & $\begin{array}{l}\text { Squared average interest rate on loans. } \\
\text { In percent. }\end{array}$ & $\begin{array}{l}\text { World Bank, respective } \\
\text { central banks and own } \\
\text { calculations }\end{array}$ \\
\hline $\begin{array}{l}\text { Strength } \\
\text { of legal } \\
\text { rights } \\
\text { index* }\end{array}$ & $L E G A L$ & $\begin{array}{l}\text { The strength of legal rights index } \\
\text { measures the degree to which collateral } \\
\text { and bankruptcy laws protect the rights } \\
\text { of borrowers and lenders and thus facilitate } \\
\text { lending. } 0=\text { low to } 12=\text { high. }\end{array}$ & World Bank \\
\hline Time (days) & TIMEENF & $\begin{array}{l}\text { The number of days it takes to enforce } \\
\text { a contract in the respective country. }\end{array}$ & $\begin{array}{l}\text { World Bank (Doing } \\
\text { Business Reports) }\end{array}$ \\
\hline Credit to GDP & $C R E D_{G}$ & $\begin{array}{l}\text { Total private sector credit over GDP. } \\
\text { In percent. }\end{array}$ & $\begin{array}{l}\text { World Bank and respective } \\
\text { central banks }\end{array}$ \\
\hline $\begin{array}{l}\text { Deposit } \\
\text { to GDP }\end{array}$ & $D E P_{G}$ & Total banking deposits over GDP. In percent. & $\begin{array}{l}\text { World Bank and respective } \\
\text { central banks }\end{array}$ \\
\hline $\begin{array}{l}\text { Remittances } \\
\text { to GDP }\end{array}$ & $R E M I T_{G}$ & $\begin{array}{l}\text { Personal remittances received over GDP. } \\
\text { In percent. }\end{array}$ & World Bank \\
\hline $\begin{array}{l}\text { Interaction } \\
\text { variable }\end{array}$ & EuroEL1 & $\begin{array}{l}\text { Interaction variable between a dummy } \\
\text { variable denoting countries that are part } \\
\text { of the Eurozone and the lagged excess } \\
\text { liquidity ratio. }\end{array}$ & Author \\
\hline $\begin{array}{l}\text { Interaction } \\
\text { variable }\end{array}$ & DEP2008 & $\begin{array}{l}\text { Interaction variable between a dummy } \\
\text { variable denoting the year } 2008, \text { when } \\
\text { the GFC effects appeared in most } \\
\text { of the sample countries, and the deposit-to- } \\
\text { GDP ratio. }\end{array}$ & Author \\
\hline
\end{tabular}

Note: * The LEGAL index data were interpolated from 2000 to 2003. The linear and cubic spline interpolation rendered the same results. The index is a slowly moving variable with little variability.

Source: Author

The descriptive statistics are presented in Table 4. 
Table 4: Descriptive statistics

\begin{tabular}{|c|c|c|c|c|}
\hline Variable & Mean & Min. & Max. & $\begin{array}{l}\text { Standard } \\
\text { deviation }\end{array}$ \\
\hline Excess liquidity to total assets & 15.7 & -14.3 & 57.1 & 13.3 \\
\hline Volatility of credit to GDP & -0.8 & -37.2 & 33.7 & 13.4 \\
\hline Squared lending interest rate & 117.2 & 2.2 & $2,899.8$ & 268.1 \\
\hline Strength of legal rights & 6.9 & 3.0 & 10.0 & 1.6 \\
\hline Time to enforce a contract & 605.2 & 209.0 & $1,445.0$ & 265.5 \\
\hline Credit to GDP & 45.0 & 7.1 & 101.3 & 17.7 \\
\hline Deposits to GDP & 43.4 & 5.5 & 79.0 & 14.0 \\
\hline Remittance inflows to GDP & 3.9 & 0.1 & 34.5 & 6.1 \\
\hline Interaction variable EuroEL1 & 0.5 & 0.0 & 1.0 & 0.5 \\
\hline Interaction variable DEP2008 & 0.5 & 0.0 & 1.0 & 0.5 \\
\hline
\end{tabular}

Source: Author

\subsection{Model description}

The first-stage estimated model represents an enhanced version of Saxegaard's (2006) technique. The model is augmented with regulatory, macroeconomic and banking indicators and, most importantly, includes institutional indicators, which are of utmost relevance in terms of EETEs. The estimations of the initially specified model started with a larger set of independent variables. To save degrees of freedom due to the small dataset, insignificant variables were dropped from the model, following Saxegaard's approach. Given the dynamic nature of excess liquidity and endogeneity concerns pertaining to EL, loans and deposits, Equation 6 is estimated using the dynamic GMM. To utilize a larger dataset and benefit from cross-sectional variations, a panel dataset is employed.

$$
\begin{aligned}
& E L_{i t}=\alpha_{i}+\alpha_{1} E L_{i^{\prime} t-1}+\alpha_{2} \text { VOLCRED }_{i, t}+\alpha_{3} I S Q R D_{i, t}+\alpha_{4} L E G A L_{i, t}+\alpha_{5} \text { CRED }_{G i, t}+ \\
& +\alpha_{6} D E P_{G i, t}+\alpha_{7} R E M I T_{G i, t}+\alpha_{8} \text { Dyears }^{2}+u_{i}+\varepsilon_{i, t}
\end{aligned}
$$

VOLCRED is the three-year moving average of the standard deviation of private sector credit to GDP to account for credit risk, ISQRD is the squared lending interest rate controlling for the backward-bending lending interest rate to account for credit rationing, LEGAL is a World Bank index measuring the degree to which collateral and bankruptcy laws protect the rights of borrowers and lenders and thus facilitate lending $(0=$ weak to $12=$ strong $), R E M I T_{G}$ represents remittance inflows to GDP ratio in the receiving country, $C R E D_{G}$ is the ratio of private sector credit to GDP, whereas $D E P_{G}$ 
is the ratio of deposits to GDP, $\alpha_{8}$ DYears represent year dummies 2001 through 2018 (excluding the year 2000 to avoid the dummy trap) to allow for aggregate time effects. These dummy variables are exogenous, because the passage of time is exogenous and so they act as their own instruments.

Possible endogenous variables in the model are $C R E D_{G}, i_{D}$ and $i_{L}$, because they are determined by banks based on their business models and forecasts and are therefore instrumented with lags within the GMM framework. Exogenous variables enter as instruments on their own. As discussed in the theoretical section, the $D E P_{G}$ variable is treated as exogenous since it does not react to the deposit rate but it is rather determined by structural factors outside banks' control.

As expected, most of the variables in the sample are stationary. The unit root tests indicate ambiguous results for a very few series, possibly due to the rejecting power in small samples such as ours. The sample series are finite and transformed into ratios as an adjusting scale for all the countries. The ratios are bounded between certain values and are not expected to grow or decrease indefinitely as in the case of random walks.

The parameter estimates from the first stage in Equation 6 are used in the second stage to create dynamic forecasts of $R_{P}$ and $R_{T}$.

$$
\begin{aligned}
& E L_{i t}^{p}=\alpha \hat{c}+\hat{\alpha}_{1}^{p} E L_{t-1}^{p}+\widehat{\alpha}_{2}(L) X_{t}^{1} \\
& E L_{i t}^{I} .=(1-\alpha) \hat{c}+\hat{\alpha}_{1}^{I} E L_{t-1}^{I}+\widehat{\alpha}_{3}(L) X_{t}^{2}
\end{aligned}
$$

Where $E L^{p}$ and $E L^{I}$ are the respective ratios of $R_{P}$ and $R_{I}$ to total assets, $\hat{c}$ is the estimated constant and $\hat{\alpha}_{1}^{I}, \widehat{\alpha}_{2}, \widehat{\alpha}_{1}^{I}$ and $\widehat{\alpha}_{3}$ are parameter estimates, $L$ is the lag operator and the $X^{1}$ and $X^{2}$ represent vectors of explanatory variables.

$$
\begin{aligned}
& X^{1}=\{\text { VOLCRED, ISQRD, LEGAL }\} \\
& X^{2}=\left\{\text { REMIT }_{G}, \text { CRED }_{G}, D_{E} P_{G}\right\}
\end{aligned}
$$

The disaggregation is carried out by separating $X^{1}$ and $X^{2}$ and multiplying the respective explanatory variables with parameter estimates to generate separate fitted values for $E L_{i t}^{p}$ and $E L_{i t}^{I}$. The constant term, however, is divided between $R_{P}$ and $R_{I}$ based on the $\alpha$ coefficient, which needs to be chosen by the researcher, conditional on:

$$
0<\alpha<1
$$

and

$$
\widehat{\alpha}_{1}^{p} E L_{t}^{p}+\widehat{\alpha}_{1}^{I} E L_{t}^{I}=\widehat{\alpha}_{1}\left(E L_{t}^{p}+E L_{t}^{I}\right) \Rightarrow \widehat{\alpha}_{1}^{p}+\hat{\alpha}_{1}^{I}=\widehat{\alpha}_{1}
$$

If estimated $\alpha \neq 0$, Equation 9 is a dynamic forecast of $E L^{p}$ and $E L^{I}$ and for each period, the sum of $E L^{p}$ and $E L^{I}$ equals the dynamic forecast of EL. 
Any combination that satisfy the condition in Equation 8 is considered feasible.

As Saxegaard (2006) points out, Equation 9 may not always render positive values for all the estimated fitted values of $E L^{P}$ and $E L^{I}$ for whatever combination of $\alpha$, as is the case with four countries, shown below. We started the disaggregation exercise shown in 4.1 by arbitrarily setting $\widehat{\alpha}_{1}^{p}$ and $\hat{\alpha}_{1}^{I}$ to 0.5 , and then conducted sensitivity analysis with all the range of alphas from 0 to 1 using different combinations, e.g., 0.2 and $0.8,0.4$ and 0.6 , and so on. The overall trend stays relatively the same with any combination and the narrative does not change substantially; nevertheless, the results indicated that more countries performed better with this combination of alphas: $\widehat{\alpha}_{1}^{p}=0.35$ and $\hat{\alpha}_{1}^{I}=0.65$. In future research, it would be worth estimating the alpha parameter that disaggregates precautionary from involuntary reserves by endogenizing it inside the model instead of calibrating it.

\section{Research Findings}

The primary goal of the empirical exercise is to disaggregate and determine the prevailing motive for EL accumulation rather than precision of the coefficient estimation. The estimated coefficients should be interpreted at least for the economic sense. Table 5 presents the estimated results from the dynamic panel model using one-step GMM. ${ }^{13}$

The positive coefficient on the lagged $E L$ (baseline model) in CE countries and Baltics indicates that EL tends to persist. The fact that EETEs were prone to EL for more than 19 years supports the inertia argument. In EETEs, commercial banks' demand for $R_{P}$ is mainly due to changes in credit uncertainty and the strength of the laws implemented in the lending process. Higher volatility in lending activity reflects higher uncertainty for commercial banks, leading to higher build-up of EL. Deposit and lending rates turned out to be statistically insignificant, supporting our argument in Section 2 that EL is independent of interest rates; banks deny credit even at high $r_{L}$ and lack of other alternatives to save money leaves deposits in banks regardless of the $r_{D}$. Thus, deposits are exogenous. This argument is greatly supported by the falling trend of $r_{D}$ in the recent years and the persistence of EL. As expected, LEGAL is highly significant in these economies. A better perception of the strength of legal rights is expected to reduce the information asymmetry and induce banks to utilize more EL, meaning higher transparency in disclosing financial reports and tax-paying evidence. In some EETEs, enterprises tend to present unrealistic types of accounting reports: one with deflated numbers for the tax authorities and another one with inflated profits for the banks (Hellström, 2009; Kastrati et al., 2018). Even though the $L E G A L$ index indicates an improving trend in EETEs, these improvements could represent "paper progress", thus not necessarily reflecting the actual reality.

13 The estimated results were controlled for robustness by using a range of different sets of alphas with different benchmarks for $M L$. The estimated coefficients are qualitatively and quantitatively similar and the general trend of $R_{P}$ and $R_{I}$ stays the same. 
Table 5: Determinants of excess liquidity 2000-2019, CE and Baltics

\begin{tabular}{|c|c|c|c|c|c|c|c|c|c|}
\hline & \multicolumn{2}{|c|}{$\begin{array}{c}\text { Benchmark } 15 \% \\
\text { (CE and Baltics) }\end{array}$} & \multicolumn{2}{|c|}{$\begin{array}{l}\text { Benchmark } 25 \% \\
\text { for all countries }\end{array}$} & \multicolumn{2}{|c|}{$\begin{array}{l}\text { Benchmark } 20 \% \\
\text { for all countries }\end{array}$} & \multicolumn{2}{|c|}{$\begin{array}{l}\text { Benchmark } 10 \% \\
\text { for all countries }\end{array}$} & \multirow[b]{2}{*}{ Year } \\
\hline & & Year & & Year & & Year & & Year & \\
\hline Variables & 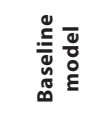 & 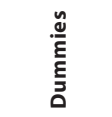 & 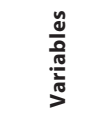 & $\frac{\text { gू }}{\text { हू }}$ & $\frac{n}{\frac{n}{0}}$ & 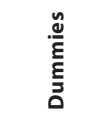 & $\frac{\frac{n}{0}}{\frac{\pi}{\frac{\pi}{2}}}$ & 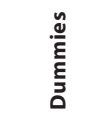 & 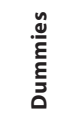 \\
\hline Constant & $\begin{array}{c}47.60^{* * *} \\
(8.357)\end{array}$ & $\begin{array}{c}-11.45^{* * *} \\
(3.482)\end{array}$ & $\begin{array}{l}45.24^{* * *} \\
(8.289)\end{array}$ & $\begin{array}{c}-11.45^{* * *} \\
(3.482)\end{array}$ & $\begin{array}{c}46.66^{* * *} \\
(8.326)\end{array}$ & $\begin{array}{c}-11.45^{* * *} \\
(3.482)\end{array}$ & $\begin{array}{c}49.48^{* * *} \\
(8.431)\end{array}$ & $\begin{array}{c}-11.45^{* * *} \\
(3.482)\end{array}$ & y2001 \\
\hline L.EL & $\begin{array}{l}0.718 * * * \\
(0.058)\end{array}$ & $\begin{array}{c}-8.519 * * \\
(3.361)\end{array}$ & $\begin{array}{l}0.718^{* * *} \\
(0.058)\end{array}$ & $\begin{array}{c}-8.519 * * \\
(3.361)\end{array}$ & $\begin{array}{l}0.718^{* * *} \\
(0.058)\end{array}$ & $\begin{array}{c}-8.519 * * \\
(3.361)\end{array}$ & $\begin{array}{l}0.718^{* * *} \\
(0.058)\end{array}$ & $\begin{array}{c}-8.519 * * \\
(3.361)\end{array}$ & y2002 \\
\hline \multirow{2}{*}{$\begin{array}{l}\text { Variables } \\
\text { explaining } \\
\text { precaution- } \\
\text { ary excess } \\
\text { liquidity }\end{array}$} & $\begin{array}{l}- \\
-\end{array}$ & $\begin{array}{c}-10.46^{* * *} \\
(3.287)\end{array}$ & $\begin{array}{l}- \\
-\end{array}$ & $\begin{array}{c}-10.46^{* * *} \\
(3.287)\end{array}$ & $\begin{array}{l}- \\
-\end{array}$ & $\begin{array}{c}-10.46^{* * *} \\
(3.287)\end{array}$ & $\begin{array}{l}- \\
-\end{array}$ & $\begin{array}{c}-10.46^{* * *} \\
(3.287)\end{array}$ & y2003 \\
\hline & - & $\begin{array}{l}-7.743^{* *} \\
(3.242)\end{array}$ & $\begin{array}{l}- \\
-\end{array}$ & $\begin{array}{c}-7.743^{* *} \\
(3.242)\end{array}$ & - & $\begin{array}{c}-7.743^{* *} \\
(3.242)\end{array}$ & - & $\begin{array}{l}-7.743^{* *} \\
(3.242)\end{array}$ & y2004 \\
\hline VOLCRED & $\begin{array}{c}0.315^{* * *} \\
(0.114)\end{array}$ & $\begin{array}{l}-2.717 \\
(3.017)\end{array}$ & $\begin{array}{l}0.315^{* * *} \\
(0.114)\end{array}$ & $\begin{array}{l}-2.717 \\
(3.017)\end{array}$ & $\begin{array}{c}0.315^{* * *} \\
(0.114)\end{array}$ & $\begin{array}{l}-2.717 \\
(3.017)\end{array}$ & $\begin{array}{c}0.315^{* * *} \\
(0.114)\end{array}$ & $\begin{array}{l}-2.717 \\
(3.017)\end{array}$ & y2005 \\
\hline LEGAL & $\begin{array}{c}-1.999 * * * \\
(0.650)\end{array}$ & $\begin{array}{c}0.318 \\
(2.830)\end{array}$ & $\begin{array}{c}-1.999^{* * *} \\
(0.650)\end{array}$ & $\begin{array}{c}0.318 \\
(2.830)\end{array}$ & $\begin{array}{c}-1.999 * * * \\
(0.650)\end{array}$ & $\begin{array}{c}0.318 \\
(2.830)\end{array}$ & $\begin{array}{c}-1.999 * * * \\
(0.650)\end{array}$ & $\begin{array}{c}0.318 \\
(2.830)\end{array}$ & y2006 \\
\hline EuroEL1 & $\begin{array}{c}-0.169 * \\
(0.095)\end{array}$ & $\begin{array}{l}-3.335 \\
(2.659)\end{array}$ & $\begin{array}{c}-0.169^{*} \\
(0.095)\end{array}$ & $\begin{array}{l}-3.335 \\
(2.659)\end{array}$ & $\begin{array}{c}-0.169^{*} \\
(0.095)\end{array}$ & $\begin{array}{l}-3.335 \\
(2.659)\end{array}$ & $\begin{array}{c}-0.169^{*} \\
(0.095)\end{array}$ & $\begin{array}{l}-3.335 \\
(2.659)\end{array}$ & y2007 \\
\hline \multirow{2}{*}{$\begin{array}{l}\text { Variables } \\
\text { explaining } \\
\text { involuntary } \\
\text { excess } \\
\text { liquidity }\end{array}$} & - & $\begin{array}{c}0.080 \\
(2.547)\end{array}$ & - & $\begin{array}{c}0.080 \\
(2.547)\end{array}$ & - & $\begin{array}{c}0.080 \\
(2.547)\end{array}$ & - & $\begin{array}{c}0.080 \\
(2.547)\end{array}$ & y2008 \\
\hline & - & $\begin{array}{c}2.655 \\
(2.458)\end{array}$ & - & $\begin{array}{c}2.655 \\
(2.458)\end{array}$ & - & $\begin{array}{c}2.655 \\
(2.458)\end{array}$ & - & $\begin{array}{c}2.655 \\
(2.458)\end{array}$ & y2009 \\
\hline CREDGDP & $\begin{array}{c}-0.521^{* * *} \\
(0.102) \\
\end{array}$ & - & $\begin{array}{c}-0.521^{* * *} \\
(0.102)\end{array}$ & - & $\begin{array}{c}-0.521^{* * *} \\
(0.102) \\
\end{array}$ & - & $\begin{array}{c}-0.521^{* * *} \\
(0.102) \\
\end{array}$ & - & y2010 \\
\hline DEPGDP & $\begin{array}{c}0.015^{*} \\
(0.093)\end{array}$ & $\begin{array}{l}-0.029 \\
(2.457)\end{array}$ & $\begin{array}{c}0.015^{*} \\
(0.093)\end{array}$ & $\begin{array}{l}-0.029 \\
(2.457)\end{array}$ & $\begin{array}{l}0.015^{*} \\
(0.093)\end{array}$ & $\begin{array}{l}-0.029 \\
(2.457)\end{array}$ & $\begin{array}{c}0.015^{*} \\
(0.093)\end{array}$ & $\begin{array}{l}-0.029 \\
(2.457)\end{array}$ & y2011 \\
\hline REMIT & $\begin{array}{c}-0.560^{* *} \\
(0.227)\end{array}$ & $\begin{array}{c}0.610 \\
(2.468)\end{array}$ & $\begin{array}{c}-0.560^{* *} \\
(0.227)\end{array}$ & $\begin{array}{c}0.610 \\
(2.468)\end{array}$ & $\begin{array}{c}-0.560^{* *} \\
(0.227)\end{array}$ & $\begin{array}{c}0.610 \\
(2.468)\end{array}$ & $\begin{array}{c}-0.560^{* *} \\
(0.227)\end{array}$ & $\begin{array}{c}0.610 \\
(2.468)\end{array}$ & y2012 \\
\hline $\begin{array}{l}\text { Sargan test } \\
\text { of overiden- } \\
\text { tifying } \\
\text { restrictions }\end{array}$ & - & $\begin{array}{l}-0.397 \\
(2.487)\end{array}$ & - & $\begin{array}{l}-0.397 \\
(2.487)\end{array}$ & - & $\begin{array}{l}-0.397 \\
(2.487)\end{array}$ & $\begin{array}{l}- \\
-\end{array}$ & $\begin{array}{l}-0.397 \\
(2.487)\end{array}$ & y2013 \\
\hline \multirow{3}{*}{$\begin{array}{l}2=193.73 \\
{[0.431]}\end{array}$} & $\begin{array}{l}- \\
-\end{array}$ & $\begin{array}{l}-1.765 \\
(2.600)\end{array}$ & - & $\begin{array}{l}-1.765 \\
(2.600)\end{array}$ & $\begin{array}{l}- \\
-\end{array}$ & $\begin{array}{l}-1.765 \\
(2.600)\end{array}$ & $\begin{array}{l}- \\
-\end{array}$ & $\begin{array}{l}-1.765 \\
(2.600)\end{array}$ & y2014 \\
\hline & - & $\begin{array}{c}0.808 \\
(2.578)\end{array}$ & - & $\begin{array}{c}0.808 \\
(2.578)\end{array}$ & - & $\begin{array}{c}0.808 \\
(2.578)\end{array}$ & - & $\begin{array}{c}0.808 \\
(2.578)\end{array}$ & y2015 \\
\hline & - & $\begin{array}{l}-1.000 \\
(2.626)\end{array}$ & - & $\begin{array}{l}-1.000 \\
(2.626)\end{array}$ & - & $\begin{array}{l}-1.000 \\
(2.626)\end{array}$ & - & $\begin{array}{l}-1.000 \\
(2.626)\end{array}$ & y2016 \\
\hline \multirow{3}{*}{$\begin{array}{l}\text { Observa- } \\
\text { tions } \\
\text { Number } \\
\text { of countries }\end{array}$} & $\begin{array}{c}216 \\
12 \\
\end{array}$ & $\begin{array}{l}-1.425 \\
(2.653)\end{array}$ & - & $\begin{array}{l}-1.425 \\
(2.653)\end{array}$ & - & $\begin{array}{l}-1.425 \\
(2.653)\end{array}$ & - & $\begin{array}{l}-1.425 \\
(2.653)\end{array}$ & y2017 \\
\hline & $\begin{array}{l}- \\
- \\
\end{array}$ & $\begin{array}{l}-2.611 \\
(2.846)\end{array}$ & $\begin{array}{l}- \\
- \\
-\end{array}$ & $\begin{array}{l}-2.611 \\
(2.846)\end{array}$ & $\begin{array}{l}- \\
- \\
\end{array}$ & $\begin{array}{l}-2.611 \\
(2.846)\end{array}$ & $\begin{array}{l}- \\
-\end{array}$ & $\begin{array}{l}-2.611 \\
(2.846)\end{array}$ & y2018 \\
\hline & $\begin{array}{l}- \\
-\end{array}$ & $\begin{array}{l}-2.975 \\
(2.766)\end{array}$ & $\begin{array}{l}- \\
-\end{array}$ & $\begin{array}{l}-2.975 \\
(2.766)\end{array}$ & $\begin{array}{l}- \\
-\end{array}$ & $\begin{array}{l}-2.975 \\
(2.766)\end{array}$ & $\begin{array}{l}- \\
-\end{array}$ & $\begin{array}{l}-2.975 \\
(2.766)\end{array}$ & y2019 \\
\hline
\end{tabular}

Note: Standard errors in parentheses ${ }^{* *} p<0.01,{ }^{* *} p<0.05,{ }^{*} p<0.1$

Source: Estimated by the Author in Stata 16 
Table 6: Determinants of excess liquidity 2000-2019, SEE

\begin{tabular}{|c|c|c|c|c|c|c|c|c|c|}
\hline & \multicolumn{2}{|c|}{$\begin{array}{l}\text { Benchmark } 20 \% \\
\text { for all SEE countries }\end{array}$} & \multicolumn{2}{|c|}{$\begin{array}{l}\text { Benchmark } 25 \% \\
\text { for all countries }\end{array}$} & \multicolumn{2}{|c|}{$\begin{array}{l}\text { Benchmark } 15 \% \\
\text { for all countries }\end{array}$} & \multicolumn{2}{|c|}{$\begin{array}{l}\text { Benchmark } 10 \% \\
\text { for all countries }\end{array}$} & \multirow[b]{2}{*}{ Year } \\
\hline & & Year & & Year & & Year & & Year & \\
\hline Variables & $\begin{array}{l}\text { Baseline } \\
\text { model }\end{array}$ & Dummies & Variables & Dummies & Variables & Dummies & Variables & Dummies & Dummies \\
\hline Constant & $\begin{array}{l}-20.900 \\
(13.450)\end{array}$ & $\begin{array}{c}57.370 * * * \\
(15.030)\end{array}$ & $\begin{array}{c}-23.230^{*} \\
(13.520)\end{array}$ & $\begin{array}{c}57.370^{* * *} \\
(15.030)\end{array}$ & $\begin{array}{l}-18.560 \\
(13.390)\end{array}$ & $\begin{array}{c}57.370 * * * \\
(15.030)\end{array}$ & $\begin{array}{l}-16.220 \\
(13.340)\end{array}$ & $\begin{array}{c}57.370 * * * \\
(15.030)\end{array}$ & y2001 \\
\hline L.EL & $\begin{array}{c}0.533^{* * *} \\
(0.076)\end{array}$ & $\begin{array}{c}43.730^{* * *} \\
(13.610)\end{array}$ & $\begin{array}{c}0.533^{* * *} \\
(0.076)\end{array}$ & $\begin{array}{c}43.730 * * * \\
(13.610)\end{array}$ & $\begin{array}{l}0.533^{* * *} \\
(0.076)\end{array}$ & $\begin{array}{c}43.730^{* * *} \\
(13.610)\end{array}$ & $\begin{array}{c}0.533^{* * *} \\
(0.076)\end{array}$ & $\begin{array}{c}43.730 * * * \\
(13.610)\end{array}$ & y2002 \\
\hline \multirow{2}{*}{$\begin{array}{l}\text { Variables } \\
\text { explaining } \\
\text { precaution- } \\
\text { ary excess } \\
\text { liquidity }\end{array}$} & - & $\begin{array}{c}40.400^{* * *} \\
(11.820)\end{array}$ & - & $\begin{array}{c}40.400^{* * *} \\
(11.820)\end{array}$ & $\begin{array}{l}- \\
-\end{array}$ & $\begin{array}{c}40.400 * * * \\
(11.820)\end{array}$ & - & $\begin{array}{c}40.400^{* * *} \\
(11.820)\end{array}$ & y2003 \\
\hline & $\begin{array}{l}- \\
-\end{array}$ & $\begin{array}{c}45.580^{* * *} \\
(10.530)\end{array}$ & $\begin{array}{l}- \\
-\end{array}$ & $\begin{array}{l}45.580^{* * *} \\
(10.530)\end{array}$ & $\begin{array}{l}- \\
-\end{array}$ & $\begin{array}{l}45.580 * * * \\
(10.530)\end{array}$ & - & $\begin{array}{l}45.580 * * * \\
(10.530)\end{array}$ & y2004 \\
\hline ISQRD & $\begin{array}{l}-0.024^{* *} \\
(0.011)\end{array}$ & $\begin{array}{c}29.970 * * * \\
(9.669)\end{array}$ & $\begin{array}{l}-0.024^{* *} \\
(0.011)\end{array}$ & $\begin{array}{l}29.970 * * * \\
(9.669)\end{array}$ & $\begin{array}{c}-0.024^{* *} \\
(0.011)\end{array}$ & $\begin{array}{c}29.970^{* * *} \\
(9.669)\end{array}$ & $\begin{array}{l}-0.0238^{* *} \\
(0.011)\end{array}$ & $\begin{array}{l}29.970 * * * \\
(9.669)\end{array}$ & y2005 \\
\hline TIMEENF & $\begin{array}{c}-0.030^{* *} \\
(0.013)\end{array}$ & $\begin{array}{c}28.680^{* * *} \\
(8.797)\end{array}$ & $\begin{array}{l}-0.030^{* *} \\
(0.013)\end{array}$ & $\begin{array}{c}28.680^{* * *} \\
(8.797)\end{array}$ & $\begin{array}{c}-0.030^{* *} \\
(0.013)\end{array}$ & $\begin{array}{c}28.680^{* * * *} \\
(8.797)\end{array}$ & $\begin{array}{l}-0.030^{* *} \\
(0.013)\end{array}$ & $\begin{array}{l}28.680^{* * * *} \\
(8.797)\end{array}$ & y2006 \\
\hline DEP2008 & $\begin{array}{c}-0.744^{*} \\
(0.419)\end{array}$ & $\begin{array}{c}25.530 * * * \\
(7.143)\end{array}$ & $\begin{array}{c}-0.744^{*} \\
(0.419)\end{array}$ & $\begin{array}{c}25.530 * * * \\
(7.143)\end{array}$ & $\begin{array}{c}-0.744^{*} \\
(0.419)\end{array}$ & $\begin{array}{c}25.530^{* * * *} \\
(7.143)\end{array}$ & $\begin{array}{c}-0.744^{*} \\
(0.419)\end{array}$ & $\begin{array}{c}25.530 * * * \\
(7.143)\end{array}$ & y2007 \\
\hline \multirow{2}{*}{$\begin{array}{l}\text { Variables } \\
\text { explaining } \\
\text { involuntary } \\
\text { excess } \\
\text { liquidity }\end{array}$} & $\begin{array}{l}- \\
-\end{array}$ & $\begin{array}{l}41.790^{* *} \\
(19.450)\end{array}$ & - & $\begin{array}{c}41.790^{* *} \\
(19.450)\end{array}$ & - & $\begin{array}{c}41.790^{* *} \\
(19.450)\end{array}$ & - & $\begin{array}{c}41.790^{* *} \\
(19.450)\end{array}$ & y2008 \\
\hline & $\begin{array}{l}- \\
-\end{array}$ & $\begin{array}{c}13.640^{* *} \\
(6.126)\end{array}$ & - & $\begin{array}{c}13.640^{* *} \\
(6.126)\end{array}$ & - & $\begin{array}{c}13.640^{* *} \\
(6.126)\end{array}$ & $\begin{array}{l}- \\
-\end{array}$ & $\begin{array}{c}13.640^{* *} \\
(6.126)\end{array}$ & y2009 \\
\hline \multirow{3}{*}{ CREDGDP } & $\begin{array}{c}0.858^{* * *} \\
(0.273)\end{array}$ & $\begin{array}{c}12.810^{* *} \\
(5.981)\end{array}$ & $\begin{array}{c}0.858^{* * *} \\
(0.273)\end{array}$ & $\begin{array}{c}12.810^{* *} \\
(5.981)\end{array}$ & $\begin{array}{c}0.858^{* * *} \\
(0.273)\end{array}$ & $\begin{array}{c}12.810^{* *} \\
(5.981)\end{array}$ & $\begin{array}{c}0.858^{* * *} \\
(0.273)\end{array}$ & $\begin{array}{c}12.810^{* *} \\
(5.981)\end{array}$ & y2010 \\
\hline & $\begin{array}{l}- \\
-\end{array}$ & $\begin{array}{c}13.130 * * \\
(6.086)\end{array}$ & - & $\begin{array}{c}13.130^{* * *} \\
(6.086)\end{array}$ & - & $\begin{array}{c}13.130^{* *} \\
(6.086)\end{array}$ & $\begin{array}{l}- \\
-\end{array}$ & $\begin{array}{c}13.130^{* *} \\
(6.086)\end{array}$ & y2011 \\
\hline & $\begin{array}{l}- \\
-\end{array}$ & $\begin{array}{c}13.750 * * \\
(5.994)\end{array}$ & - & $\begin{array}{c}13.750 * * \\
(5.994)\end{array}$ & - & $\begin{array}{c}13.750^{* *} \\
(5.994)\end{array}$ & $\begin{array}{l}- \\
-\end{array}$ & $\begin{array}{c}13.750^{* *} \\
(5.994)\end{array}$ & y2012 \\
\hline $\begin{array}{l}\text { Sargan test } \\
\text { of overiden- } \\
\text { tifying } \\
\text { restrictions }\end{array}$ & $\begin{array}{l}- \\
-\end{array}$ & $\begin{array}{c}13.870^{* *} \\
(6.084)\end{array}$ & - & $\begin{array}{c}13.870^{* *} \\
(6.084)\end{array}$ & - & $\begin{array}{c}13.870 * * \\
(6.084)\end{array}$ & - & $\begin{array}{c}13.870^{* *} \\
(6.084)\end{array}$ & y2013 \\
\hline \multirow{3}{*}{$\begin{array}{l}2=68.55 \\
{[0.424]}\end{array}$} & $\begin{array}{l}- \\
-\end{array}$ & $\begin{array}{c}4.831 \\
(6.021)\end{array}$ & - & $\begin{array}{l}4.831 \\
(6.021)\end{array}$ & - & $\begin{array}{c}4.831 \\
(6.021)\end{array}$ & - & $\begin{array}{c}4.831 \\
(6.021)\end{array}$ & y2014 \\
\hline & $\begin{array}{l}- \\
-\end{array}$ & $\begin{array}{c}8.595 \\
(5.886)\end{array}$ & - & $\begin{array}{c}8.595 \\
(5.886)\end{array}$ & - & $\begin{array}{c}8.595 \\
(5.886)\end{array}$ & $\begin{array}{l}- \\
-\end{array}$ & $\begin{array}{c}8.595 \\
(5.886)\end{array}$ & y2015 \\
\hline & $\begin{array}{l}- \\
-\end{array}$ & $\begin{array}{c}9.295 \\
(5.893)\end{array}$ & - & $\begin{array}{c}9.295 \\
(5.893)\end{array}$ & - & $\begin{array}{c}9.295 \\
(5.893)\end{array}$ & $\begin{array}{l}- \\
-\end{array}$ & $\begin{array}{c}9.295 \\
(5.893)\end{array}$ & y2016 \\
\hline \multirow{2}{*}{$\begin{array}{l}\text { Observa- } \\
\text { tions } \\
\text { Number } \\
\text { of countries }\end{array}$} & $\begin{array}{l}- \\
-\end{array}$ & $\begin{array}{c}9.445 \\
(5.862)\end{array}$ & - & $\begin{array}{c}9.445 \\
(5.862)\end{array}$ & - & $\begin{array}{c}9.445 \\
(5.862)\end{array}$ & $\begin{array}{l}- \\
-\end{array}$ & $\begin{array}{c}9.445 \\
(5.862)\end{array}$ & y2017 \\
\hline & - & $\begin{array}{c}5.662 \\
(5.828)\end{array}$ & - & $\begin{array}{c}5.662 \\
(5.828)\end{array}$ & - & $\begin{array}{c}5.662 \\
(5.828)\end{array}$ & $\begin{array}{l}- \\
-\end{array}$ & $\begin{array}{c}5.662 \\
(5.828)\end{array}$ & y2018 \\
\hline
\end{tabular}

Note: Standard errors in parentheses ${ }^{* *} p<0.01,{ }^{* *} p<0.05,{ }^{*} p<0.1$

Source:

On the other side, $R_{I}$ seems to be determined by two main driving causes: loans and deposits. The estimated model predicts that an increase in $C R E D_{G}$ by $1 \mathrm{pp}$, on average, 
reduces $E L$ by $0.5 \mathrm{pp}$. The estimated model predicts that banks, on average, will accumulate more $E L$ if $D E P_{G}$ increases, confirming the hypothesis that deposits play a major role in liquidity accumulation beyond banks' needs; the $R_{I}$ may reflect higher actual deposits than potential deposits.

Contrary to prior beliefs, $R E M I T_{G}$ has negative impact on banks' demand for $E L$. Remittances not circulating through the banking system and their declining trend, which may be captured by the year dummies, could explain the negative relationship. The year dummies fulfil the statistical function of attenuating cross-group correlation, if during the examined period EETEs were prone to similar effects. ${ }^{14}$

EuroEL1 predicts that Eurozone countries, on average, have less EL than the rest of the EU countries.

In SEE countries, credit rationing appears more pronounced, confirmed by the significant ISQRD (Table 6). TIMEENF is highly significant in borrowing relations, whereas the negative sign may be capturing the improving trend in some of the countries. DEP2008 indicates that the deposits played a significant role in reducing EL, as envisaged in Figure 4.

A few variables usually significant in other studies, such as $R R, N P L s$ or $r_{D}$, turned out to be insignificant in our study, indicating that this set of countries may be different.

\subsection{Disaggregation of $R_{p}$ and $R_{I}$}

The estimated results suggest that in addition to $R_{P}, R_{I}$ is present throughout the examined period. The variables explaining the $R_{I}$ seem to change the pattern more.

Figure 3 presents the EL ratio in percent (y axis), disaggregated into $R_{P}$ and $R_{r}$. All the sample countries have a strong liquidity position throughout the examined period. Before the GFC, most European countries experienced fast economic and domestic credit growth. In many Central Eastern and South Eastern European (CESEE) countries, this was fuelled by exuberant expectations about the EU membership prospects. Most of the banks in EETEs are foreign-owned, so much of the bank lending was frequently funded by foreign parent banks. The subsidiaries were often the largest source of revenue for the parent banks. The $R_{P}$ during this period was fairly low or at times non-existent. Poland and Hungary are typical examples.

The GFC represents a common factor and a special circumstance during which $E L$ declined or slowed down in most countries. The increasing trend in $R_{P}$ soon after the onset of the GFC is consistent with the lack of market confidence, increased sensitivity to liquidity risk, depressed lending supply and demand and overall economic contraction. Nevertheless, $E L$ soon rebounded back to pre-crisis levels, indicating a transitory impact.

14 Structural shift dummies accounting for a possible break around the GFC turned out insignificant. 
Figure 3: Disaggregation of $R_{p}$ and $R_{l}, C E$ and Baltics
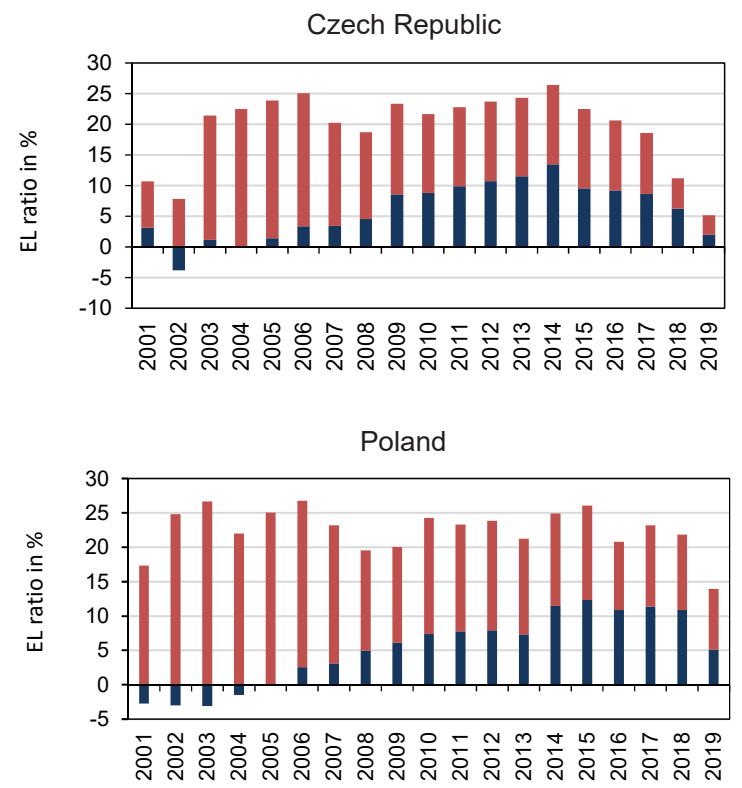

Hungary
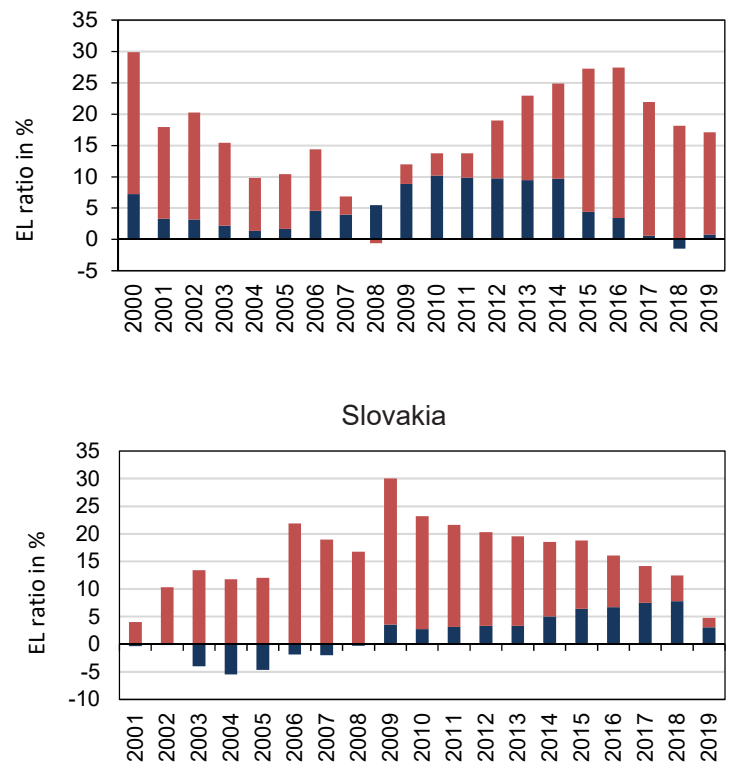

- Precautinary EL घ Involuntary EL 
Figure 3: Continuation

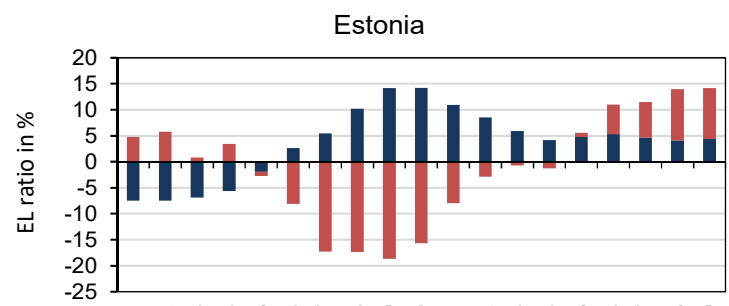

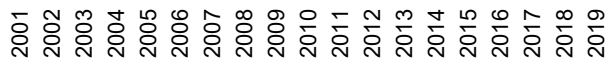
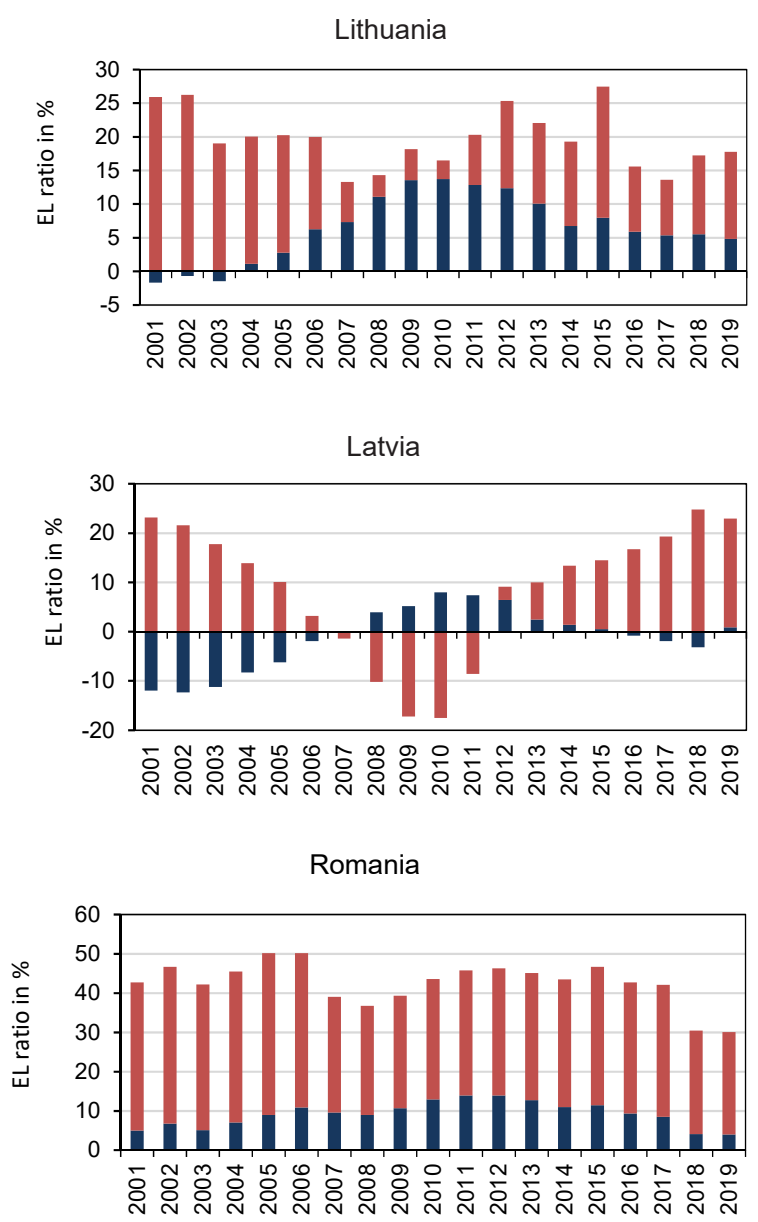

- Precautinary EL $\quad$ Involuntary EL 


\section{Figure 3: Continuation}
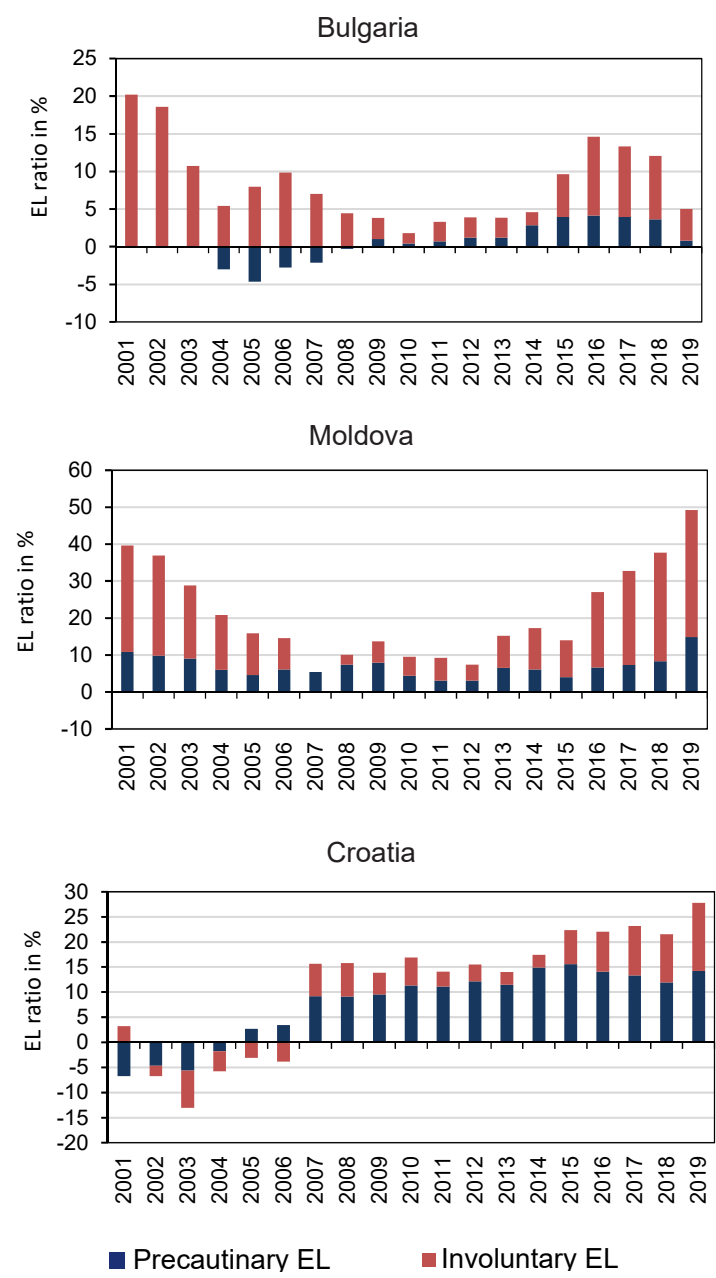

Source: Estimated by the author in Stata

The overall level of $R_{I}$ since 2012 in the Baltics, Slovenia and Slovakia can partially be explained by the ECB's expanded asset purchase programme supplying commercial banks with abundant liquidity (Baldo et al., 2017). The almost "free" liquidity provided by the ECB against certain types of collateral during a deleveraging period induced Eurozone banks to apply for more liquidity than the intended lending. ${ }^{15}$

15 The Basel III liquidity requirements treat EL as a claim on central banks, meaning that it has a zero risk weight, i.e., has no capital costs. 
Figure 4: Disaggregation of $R_{p}$ and $R_{l}$, SEE countries
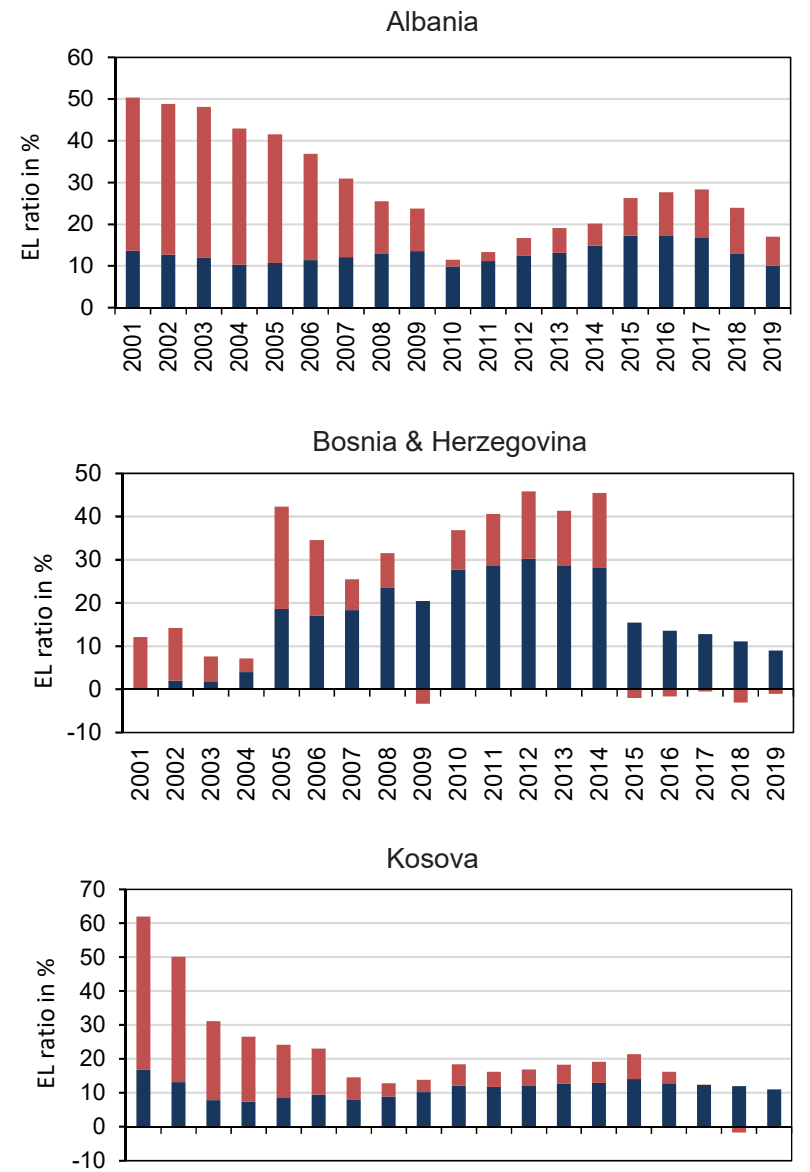

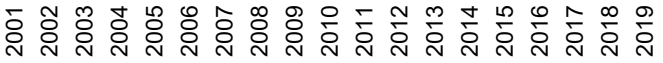

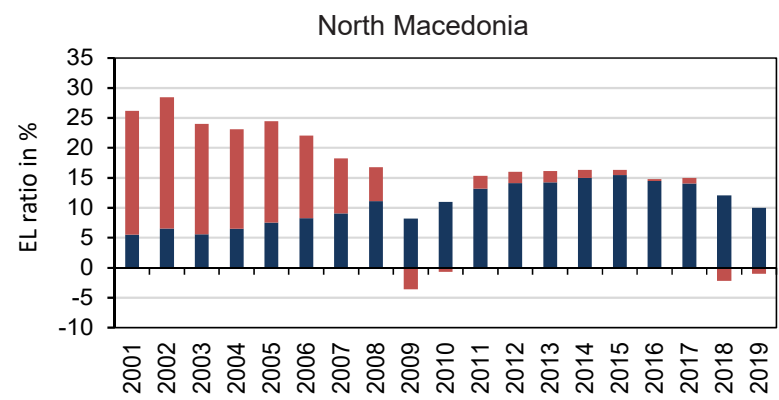

- Precautinary EL Involuntary EL 


\section{Figure 4: Continuation}

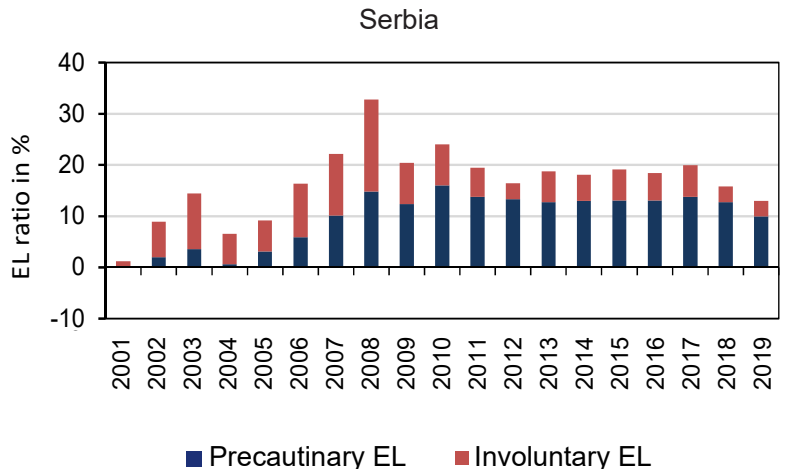

Source: Estimated by the author in Stata

The EE countries' banking systems feature the highest lending interest rates on average, yet still exhibit some of the highest levels of $R_{I}$ (14 percent), once more confirming our hypothesis that $E L$ is not a function of interest rates. The $E L$ could be signalling other structural problems pertaining to weak institutions, underdeveloped financial systems, lack of transparency and corporate governance issues. These issues may be reflected in the regulatory decisions of the National Bank of Moldova, which circumvents potential adverse activities by applying the highest $R R$ among European countries (up to 40 percent).

A few sample countries that do not fit the pattern are Croatia, Estonia, Latvia and Slovenia. In Croatia, the negative levels of EL during the beginning of the 2000s coincide with the aftermath of a banking crisis during 1998 and 1999 and over-indebtedness concerns. Negative EL appears only during panic situations i.e., right around the GFC. The improved EL measure captures stress behaviour when sudden reversals of liquidity flows incurred. The opposite of excess liquidity is liquidity shortage. Some of these banks went from excess liquidity to liquidity shortage, which is exactly what parent banks created. Parent banks were suffering from liquidity shortage themselves so they passed this into their subsidiaries abroad, while regulators could not do much about it, because of the "free movement of capital". Fast inflow reversals driven by parent banks were happening in a lot of other countries, because they all suffered from the same problem of the GFC, but it became worse in these countries.

The SEE region (outside the European Union) has persistently accumulated relatively large portions of $R_{r}$. Low absorption capacity, out-of-practice interbank market, rule of law issues, and even an exodus of people in the recent years may be some of the contributing 
factors. In Bosnia and Herzegovina, the currency board limits the lender of last resort function and parent banks limit subsidiaries' access to interbank markets, inducing accumulation of $R_{P}$ (Hasanović and Latić, 2017). The presence of EL renders interbank markets redundant. Nevertheless, continued dependency on parent bank funding to support a relatively high $r_{L}$ to $r_{D}$ still does not explain the presence of $R_{I}$ during 2005-2014. $R_{I}$ could be a consequence of domestic interest rates causing uneven liquidity adjustment to capital flows, due to frictions, credit and regulatory limits, and other impediments (IMF Technical Assistance Report, 2019). The drop of EL from 2014 onwards is related to the Central Bank's decision to remunerate excess reserves at 50 percent of the ECB's negative deposit facility rate. The negative spreads between the reinvestment yield and the remuneration of $E L$ may have reduced the $R_{I}$ from 2015 onwards.

In Kosovo, the high levels of $E L$ could be explained by low financial deepening and development, undefined political status, low absorption capacity and lack of monetary policy to stimulate bank lending due to its unilateral euroization. Despite the slowly improving market and institutional setting after the declaration of independence in 2008, $R_{I}$ has persisted mainly due to complaints regarding contract enforcement, court efficiency and financial reporting issues. Even though abundant deposits in the banking system continue to cause $R_{l}$, banks benefit by assessing fees and commissions. The National Bank of the Republic of North Macedonia has conducted an expansionary monetary policy to expand lending, by reducing the frequency of treasury bill auctions and the $R R$. Still, this did not impact on the slowly growing trend of $R_{P}$ from 2015 onwards.

\subsection{Explicit and opportunity costs from $R_{\text {, }}$}

This study proceeds to analyse explicit costs of $r_{D}$ from holding non-productive funds and implicit costs stemming from forgone opportunity investment in loans. In Table 7, the first and third columns multiply the $R_{I}$ with the $r_{D}$ to measure the explicit costs, in percent and in millions of euros respectively. The second and fourth columns multiply $R_{I}$ with $r_{L}$ to measure the implied costs (opportunity costs).

Unsurprisingly, as the country with the highest level of $E L$, Romania tops the list with highest explicit and opportunity costs, in percentage and in absolute values. Poland and the Czech Republic follow. When scaled in percentages, because of the sizes of their banking sectors, their losses are relatively small. The SEE and EE countries appear to be the "big losers" relative to the rest of the sample, in percentage terms.

Estonia and Slovenia are among the four sample countries with negative levels of $R_{I}$ in certain periods due to negative rates, so they might be considered the winners in terms of $R_{r}$. 
Table 7: Implied costs and opportunity costs from involuntary excess liquidity 2000-2018

\begin{tabular}{|c|c|c|c|c|}
\hline Country & $\begin{array}{l}\text { Average } \\
\text { implied costs } \\
\text { from involun- } \\
\text { tary excess } \\
\text { liquidity }\end{array}$ & $\begin{array}{l}\text { Average oppor- } \\
\text { tunity costs of in- } \\
\text { voluntary excess } \\
\text { liquidity from } \\
\text { forgone returns }\end{array}$ & $\begin{array}{l}\text { Average } \\
\text { implied costs } \\
\text { from involun- } \\
\text { tary excess } \\
\text { liquidity }\end{array}$ & $\begin{array}{l}\text { Average oppor- } \\
\text { tunity costs of in- } \\
\text { voluntary excess } \\
\text { liquidity from } \\
\text { forgone returns }\end{array}$ \\
\hline & (\%) & (\%) & (millions EUR) & (millions EUR) \\
\hline Albania & 1.0 & 2.2 & 59.5 & 141.0 \\
\hline Bulgaria & 0.5 & 1.0 & 283.8 & 500.0 \\
\hline $\begin{array}{l}\text { Bosnia and } \\
\text { Herzegovina }\end{array}$ & 0.3 & 0.9 & 26.2 & 88.1 \\
\hline Croatia & 0.0 & 0.0 & 2.4 & 12.8 \\
\hline Czech Republic & 0.1 & 0.5 & 381.3 & $1,825.7$ \\
\hline Estonia & 0.0 & -0.2 & -4.8 & -17.3 \\
\hline Hungary & 0.4 & 0.7 & 148.1 & 213.3 \\
\hline Kosovo & 0.5 & 2.1 & 8.7 & 40.3 \\
\hline Latvia & 0.2 & 0.5 & 57.8 & 141.0 \\
\hline Lithuania & 0.4 & 0.7 & 63.5 & 137.6 \\
\hline Moldova & 1.4 & 2.2 & 32.3 & 48.3 \\
\hline North Macedonia & 1.0 & 1.9 & 49.3 & 96.4 \\
\hline Poland & 0.6 & 1.0 & $1,369.2$ & $2,678.3$ \\
\hline Romania & 2.1 & 4.6 & $1,322.3$ & $2,763.7$ \\
\hline Serbia & 1.0 & 2.4 & 194.9 & 507.6 \\
\hline Slovakia & 0.3 & 0.7 & 164.3 & 394.1 \\
\hline Slovenia & -0.1 & -0.1 & -13.0 & -28.8 \\
\hline
\end{tabular}

Source: Author's calculations

Unsurprisingly, as the country with the highest level of $E L$, Romania tops the list with highest explicit and opportunity costs, in percentage and in absolute values. Poland and the Czech Republic follow. When scaled in percentages, because of the sizes of their banking sectors, their losses are relatively small. The SEE and EE countries appear to be the "big losers" relative to the rest of the sample, in percentage terms. 
Estonia and Slovenia are among the four sample countries with negative levels of $R_{I}$ in certain periods due to negative rates, so they might be considered the winners in terms of $R_{r}$.

\section{Conclusions and Policy Implications}

In a region where firms crave capital and lending is subdued while there is a frontier of seemingly profitable lending, the paradox of excess liquidity $(E L)$ in the banking system is not well understood, either because we have not figured out the right framework or have been working under the wrong paradigm.

In this study, the $E L$ was treated as an underutilized financial resource that does not contribute to the productive economy. This study presents a new comprehensive measure of EL by including excess reserves at central banks and excess reserves at commercial banks, to show how big of an issue EL is in EETEs. Furthermore, treating EL from regulators', banks' and consumers' perspective was a novelty. This study further presented the new methodology for estimating explicit costs and opportunity costs from accumulation of $R_{r}$. The estimated results using original estimates of EL as a dependent variable were novel for the EETE region.

Banks in EETEs operate in environments with relatively high lending rates and profitable opportunities, so theories describing developed countries exceed those explained by economic fundamentals. While in most of the Eurozone region, $E L$ became a cyclical outcome of economic contraction and intentional policy interventions after the GFC, EL in EETEs had been present for decades. Credit rationing is more pronounced in SEE countries, whereas Eurozone countries are prone to less EL. The underlying issues must be structural: weak governmental institutions and shaken confidence on markets due to historical experience in EETEs, lack of a well-developed credit culture, inadequate infrastructure, collateral availability and enforcement, financial reporting and tax payment issues and others, which make lending costly, banks conservative and borrowers discouraged. This justifies lower lending because $E L$ does not solve the adverse selection problem. Market power on the asset side enables EETEs banks to use and abuse information exclusivity and institutional failures to justify charging high rates and collateral overprotection even from good borrowers, while

profitability is higher relative to the developed Europe. Thus, high lending rates do not reflect the actual risks.

Out-of-practice interbank markets are a common feature of all the sample countries, mainly due to restrictive policies from parent banks, conservative banking cultures and presence of EL. Banks finance loans via domestic deposits and EL renders the need to borrow from central banks redundant. Consequently, policy rates in EETEs are seen 
as an opportunity cost, not a financing cost. Bank dominance and market power prevent the pass-through from policy rates to lending rates, and $R R$ are no longer binding this constraint is already above the loan supply.

Lack of competition from other financial institutions and capital markets makes deposits cheap, easy to attract and even profitable. As the only depositing alternative, banks have market power on the liability side; thus, the clients necessarily pay for all the deposit fees and commissions - which is controversial, yet supports the presence of $R_{r}$. Therefore, deposit rates are ineffective in achieving the desired level of deposits, even if nominal rates drop to zero. This confirms the hypothesis that deposits are exogenous, because they do not respond to economic stimuli.

The disaggregation exercise indicates that $R_{I}$ is present and significant throughout the examined period. Abundant deposits almost eliminate liquidity risk - explaining lower demand for $R_{P}$ relative to $R_{I}$ for all the sample countries. Eastern Europe and SouthEastern Europe have the highest levels of $R_{I}$ - unsurprisingly so, as this is the region with most issues concerning strength of legal rights protecting borrowers and lenders, court inefficiencies and corporate governance.

Structural disruptions, market frictions, supervisory pressures and high adjustment costs of deposits leave markets with $R_{r}$. Accordingly, the possibility that banks stop lending before maximizing profit is open $-R_{I}$ serves as evidence.

Explicit costs arising from $R_{I}$ reduce commercial banks' profits, whereas opportunity costs from forgone loans reduce expected profits; in some of the sample countries these costs translate to billions of euros. Thus, $R_{I}$ is costly for banks, but also for regulators due to inflationary concerns and debt creation to absorb it.

In a region where FDIs are not high, the eyes are once more turned to banks and finding ways to increase the domestic rate of investment when idle financial resources are present. Pushing banks to lend aggressively, despite $R_{l}$, may not automatically translate into productive investment - it may consequently materialize risks in the banking books and bring a new wave of bad loans.

If banks still perceive market risks, expansionary monetary policy may not convince them to expand lending, notwithstanding their stable liquidity positions. Boosting aggregate demand via fiscal policy does not solve tax and financial disclosure problems, among other structural issues. So what could be done? A key imperative is to undertake reforms to address structural inefficiencies coming from outside the banking system. First and foremost, institutions in EETEs need to ensure practical law enforcement - not only paper progress - to reduce frictions, banks' uncertainties and moral hazard behaviour from borrowers. Still, policy changes can help reduce frictions to the extent that they reflect distortions, but cannot fully wipe away the uncertainty on the loan market. 
It is in the interest of central and commercial banks to become stakeholders in improving the technical knowledge of borrowers, increasing their transparency and therefore help increase the pool of borrowers beyond the traditional ones. In effect, banks would have to compete for more clients. Finding ways to enact policies and learning how to transform $R_{I}$ into more loans could be welfare-enhancing - even as little as 1 percent could benefit a lot of firms and households.

This study can be upgraded once we have better reporting standards, longer time series with higher reporting frequency, which in turn would lead to better measurements of EL1 and EL2, and ultimately ensure more sophisticated work on excess liquidity. Future research should relate $E L$ with rates of return of non-financial economy and investment demand.

\section{References}

Agénor, P. R., Aynaoui, E. K. (2010). Excess liquidity, bank pricing rules, and monetary policy. Journal of Banking and Finance, 34, 923-933. https://doi.org/10.1016/j. jbankfin.2009.10.003

Agénor, P. R., Aizenman, J., Hoffmaister, A. W. (2004). The credit crunch in East Asia: What can bank excess liquid assets tell us? Journal of International Money and Finance, 231, 27-49. https://doi.org/10.1016/j.jimonfin.2003.08.008

Aikaeli, J. (2011). Determinants of Excess Liquidity in Tanzanian commercial banks. The African Finance Journal 113, 47-63. http://dx.doi.org/10.2139/ssrn.971750

Aliu, F., Knapkova, A., Nadirov, O. (2016). Factors affecting interest rate risk: the case of Kosovo. Paper presented at the 6th EACO International Scientific Conference.

Baldo, L., Hallinger, B., et al (2017). The distribution of excess liquidity in the euro area. European Central Bank Occasional Paper series No. 200.

Barajas, A., Chami, R., Ebeke, C., Oeking, A . (2018). What's different about monetary policy transmission in remittance-dependent countries? Journal of Development Economies, 134, 272-288. https://doi.org/10.1016/j.jdeveco.2018.05.013

Blanchard, O.J., Griffiths, M., Gruss, B. (2013). Boom, bust, recovery: Forensics of the Latvia crisis. Brookings Papers on Economic Activity, 442, 325-388.

Basel Committee on Banking Supervision (2017). Basel III: Finalising post-crisis reforms: Bank for International Settlements.

Bogoev, J., Petrevski, G. (2012). Interest rate pass-through in South East Europe: An empirical analysis. Economic Systems, 436, 571-593. https://doi.org/10.1016/j.ecosys.2012.03.001

Chami, R., Fullenkamp, C., Oeking, A. (2018). Are remittances good for labour markets in LICS, MICs and fragile states? IMF Working Paper No. 102.

Commission of the European Communities (1990). European Economy, December, 45. 
Cornett, M. M., McNutt, J. J., Strahan, P.E., Tehranian, H. (2011). Liquidity risk management and credit supply in the financial crisis. Journal of Finance and Economics, 1012, 297-312.

Darvas, Z., Pichler, D. (2018). Excess liquidity and bank lending risks in the euro area. European Parliament, Policy Issue No. 18.

De Vroey, M., Malgrange, P. (2011). The History of Macroeconomics from Keynes's General Theory to the Present. Institut de Recherches Economiques et Sociales de I'Universite Catholique de Louvain Discussion Papers No. 28.

Ding, W., Domaç, I., Ferri, G. (1998). Is there a credit crunch in East Asia? Asia Pacific Journal of Economics and Business, 22, 4-32.

Drakos, K., Nicholas, G. (2011). On the determinants of credit rationing: Firm-level evidence from transition countries. Journal of International Money and Finance 30(8): 1773-1790. https://doi.org/10.1016/j.jimonfin.2011.09.004

ECB (2019a). Monetary statistics 2000-2018. Frankfurt: European Central Bank.

ECB (2019b). Statistical bulletins 2000-2018. Frankfurt: European Central Bank.

EMMI (2019). Euribor and Eonia rates 2000 - 2018. Brussels: European Money Markets Institute.

FRED (2020). 5-Bank Asset Concentration. FRED Economic Data.

Hasanović, E., Latić, T. (2017). The Determinants of excess liquidity in the banking sector of Bosnia and Herzegovina. Working Paper HEIDWP11-2017.

Hashi, I., Toçi, V. (2010). Financing constraints, credit rationing and financing obstacles:

Evidence from firm-level data in South-Eastern Europe. Economic and Business Review, $112,29-60$.

Haughton, A., Iglesias, E. (2012). Interest rate volatility, asymmetric interest rate pass through and the monetary transmission mechanism in the Caribbean compared to US and Asia. Economic Models, 296, 2071-2089.

Hellström, K. (2009). Financial accounting quality in a European transition economy: The case of the Czech Republic. Dissertation. Stockholm School of Economics.

Huang, T.H., Liu, N.H. (2014). Bank competition in transition countries: Are those markets really in equilibrium? Empirical Economics, 47, 1283-1316.

Intercontinental Exchange (2019). Libor rates 2000-2018.

International Monetary Fund (2019). Bosnia and Herzegovina Technical Assistance report implementation of a new reserve requirement framework.

International Monetary Fund (2019a). World Economic Outlook WEO. https://www.imf.org/ external/pubs/ft/weo/2019/02/weodata/index.asp_Accessed in October 2019

IMF (2019b). Financial Soundness Indicators FSIs. Washington: International Monetary Fund.

IMF (2019c). IMF respective country reports 2003 - 2019. Washington: International Monetary Fund.

IMF (2004). Monetary policy implementation at different stages of market development.

Monetary and Financial Systems Department. Washington: International Monetary Fund. 
Jaffee, D. M., Modigliani, F. (1969). A theory and test of credit rationing. American Economic Review, 559, 850-572.

Jayaraman, T. K., Choong, C. K. (2012). Implications of excess liquidity in Fiji's banking system: An Empirical Study. Munich Personal RePEc Archive 43505.

Jazbec, B., Kastrati, A. (2011). Unlocking Growth Potential in the Balkans, in Nowotny, E., Mooslechner, P., Ritzberger-Grünwald, D., ed., Post-Crisis Growth and Integration in Europe. Vienna: Edward Elgar, pp. 70-89.

Jovanovic, B., Krstevska, A., Popovska-Kamnar, N. (2015). Can monetary policy affect economic activity under surplus liquidity? Some Evidence from Macedonia. National Bank of the Republic of North Macedonia Research Paper No. 03.

Karilaid, I., Talpsepp, T., Vaarmets, T. (2014). Implications of the liquidity crisis in the BalticNordic region. Baltic Journal of Economics (14)1-2, 35-54. https://doi.org/10.1080/14060 99X.2014.949603

Kastrati, A., Adnett, N., Toçi, V. (2018). The relationship between the output gap and excess liquidity: Evidence from Czech Republic, Estonia and Kosovo. Journal of Economics and Management, 311, 95-118. https://doi.org/10.22367/jem.2018.31.05

Kastrati, A., Pugh, G., Toçi, V. (2017). Output gap in transition economies using unobserved components method: The case of Czech Republic, Estonia and Kosovo. Economic Thought and Practice, 123, 477-500.

Khemrraj, T. (2013). Bank liquidity preference and the investment demand constraint. Economic Models, 33, 977-990. http://dx.doi.org/10.1016/j.econmod.2013.06.008

Khemrraj, T. (2010). Excess Liquidity, Oligopoly Banking and Monetary Policy in Less Developed Countries? Oxford Economic Papers, 62, 86-113. https://doi.org/10.1093/oep/gpp013

Khemrraj, T. (2007). Monetary Policy and Excess Liquidity: The Case of Guyana. Journal of Social and Economic Studies, 563, 101-127.

Manove, M., Padilla, J. A., Pagano, M. (2001). Collateral versus project screening: a model of lazy banks. RAND Journal of Economics, 432, 726-744. https://doi.org/10.2307/2696390

Männasoo, K., Meriküll. J. (2020). Credit constraints and R\&D over the boom and bust: Firm-level evidence from Central and Eastern Europe. Economic Systems, 2, 44, 100747. https://doi.org/10.1016/j.ecosys.2020.100747

Mishkin, F. (2018). Improving the use of discretion in monetary policy. International Finance, $321,224-238$.

Mishra, P., Montiel, P. (2012). How effective is monetary transmission in Low-Income Countries? A survey of the empirical evidence. IMF Working Paper 143.

Morrison, G. (1966). Liquidity preferences of commercial banks. Chicago: University of Chicago Press.

Nguyen, V .H. T., Boateng, A., Newton, D. (2015). Involuntary excess reserves, the reserve requirements and credit rationing in China. Applied Economics, 1440, 1424-1437. https://doi.org/10.1080/00036846.2014.995362 
Nguyen, V. H. T., Boateng, A. (2015). Bank excess reserves in emerging economies: A critical review and research agenda. International Review of Financial Analysis, 39, 158-166. https://doi.org/10.1016/j.irfa.2015.02.005

Nguyen, V. H. T., Boateng, A., Pham, T. T. T. (2019). Involuntary excess reserve and heterogeneous transmission of policy rates to bank lending rates in China. Empirical Economics, 57, 1023-1044. https://doi.org/10.1007/s00181-018-1468-x

OECD (1960-1987). National Accounts: Main Aggregates. Paris: Organization for Economic Cooperation and Development.

Primus, K. (2017). Excess reserves, monetary policy and financial volatility. Journal of Banking \& Finance Pages, 74, 153-168. https://doi.org/10.1016/j.jbankfin.2016.08.005

Ruffer, R. Stracca, L. (2006). What is Global Excess Liquidity and Does It Matter?, ECB Working Paper 696.

Saxegaard, M. (2006). Excess liquidity and effectiveness of monetary policy: Evidence from Sub-Saharan Africa. IMF Working Paper No. 115.

Syverson, C. (2019). Macroeconomics and Market Power: Context, Implications, and Open Questions. Journal of Economic Perspective, 333, 23-43. https://doi.org/10.1257/ jep.33.3.23

Waller, C. J., Lewarne, S. (1994). An Expository Model of Credit Rationing. Journal of Macroeconomics, 316, 539-545. https://doi.org/10.1016/0164-07049490022-1

World Bank (2019). Financial sector indicators. Washington: World Bank.

World Bank (2019). Doing Business. Washington: World Bank.

World Bank (2019). Economy and Growth Indicators. Washington: World Bank.

World Bank (2019). Worldwide Governance Indicators. Washington: World Bank. 